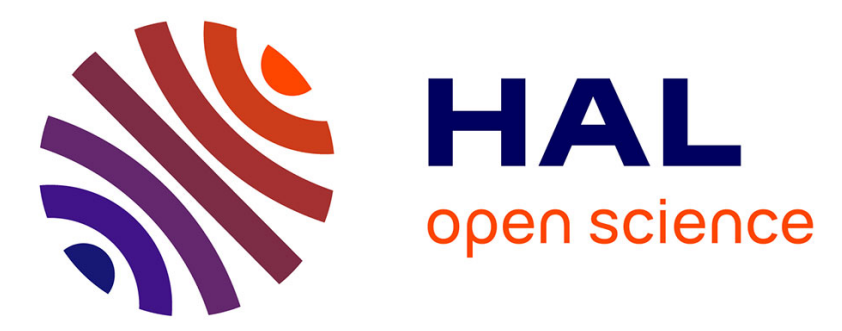

\title{
'Thus I salute the Kentucky Daisey's claim': gender, social memory, and the mythic West at a proposed Oklahoma monument
}

\author{
Dydia Delyser
}

\section{- To cite this version:}

Dydia Delyser. 'Thus I salute the Kentucky Daisey's claim': gender, social memory, and the mythic West at a proposed Oklahoma monument. cultural geographies, 2008, 15 (1), pp.63-94. 10.1177/1474474007082296 . hal-00572009

\section{HAL Id: hal-00572009 \\ https://hal.science/hal-00572009}

Submitted on 1 Mar 2011

HAL is a multi-disciplinary open access archive for the deposit and dissemination of scientific research documents, whether they are published or not. The documents may come from teaching and research institutions in France or abroad, or from public or private research centers.
L'archive ouverte pluridisciplinaire HAL, est destinée au dépôt et à la diffusion de documents scientifiques de niveau recherche, publiés ou non, émanant des établissements d'enseignement et de recherche français ou étrangers, des laboratoires publics ou privés. 


\title{
'Thus I salute the Kentucky Daisey's claim': gender, social memory, and the mythic West at a proposed Oklahoma monument
}

\author{
Dydia DeLyser
}

\author{
Department of Geography and Anthropology, Louisiana State University
}

\begin{abstract}
On 22 April 1889, at the beginning of the first Oklahoma land run when the US federal government allowed nonIndian settlers to claim what had been Native American lands, Nannita R.H. Daisey entered the newly opened territory by train to become one of the very first women to stake a quarter-section land claim, on land today part of Edmond. According to local lore, Daisy leapt from the cowcatcher of the train to stake her claim, removing her petticoat to mark the spot. Over 100 years later Edmond has proposed a bronze monument to Daisey, petticoat flying, riding on the cowcatcher, in an effort both to attract tourists with public art, and to recognize women's contributions to Oklahoma settlement. On the surface this seems a laudable attempt to re-inscribe women's lives in the history of the American West, the social memories of Oklahomans, and the landscape of contemporary Edmond - except that the story about the cowcatcher and the petticoat, though passed down in local lore for more than 100 years, is false. And that, in turn, provides feminist historical geographers with an opportunity to examine the canonization of an exaggerated version of an already heroicized tale of Euro-American conquest, and what that implies for the representation of women in the American West. In this article, in an effort to improve upon decades of superficial scholarship, and in the face of the proposed monument's mis-portrayal, I attempt to detail Daisey's biography and describe her actual deeds. But, since the lives of prominent westerners are often difficult to disentangle from the powerful romanticizing influence of the mythic West on themselves and on their representations, my attempt itself raises issues about the study and representation of westerners in the US as the article explores ways that western women have been represented, the role of a monument as the landscape representation of a western woman, and the specific gendered spatial framework for the creation of contemporary social memory that Nannita Daisey's monument and legendary tale present.
\end{abstract}

Keywords: gender • mythic West • Nannita Daisey • social memory

Tn July of 2002 the Edmond Parks Foundation in the city of Edmond, Oklahoma announced 1 its most ambitious public art project. The Foundation had voted to erect a monument to Nannita R.H. Daisey (often known as 'Kentucky Daisey'), a woman Foundation President Curt Munson described as representing 'the pioneer spirit here in Edmond in a remarkable way'; ${ }^{1}$ a woman long lauded in local histories for leaping from a moving train to become one of the first people to claim land near Edmond in Oklahoma's famous 1889 land run (where non-Indians were allowed to claim land previously set aside by the US government for Native Americans). ${ }^{2}$ The Daisey monument, planned for a city with an already active public art program, was designed to be Edmond's largest piece of public art and will be dramatic: the 1.5-times life-sized 
bronze-and-granite statue will feature a local artist's rendering of Daisey, skirts flying, leaping from the cowcatcher at the front of a train. Calling it the 'great return of Kentucky Daisey to Edmond', Edmond Life and Leisure applauded the Foundation's effort, which, by 2005, had raised thousands of dollars in private contributions, been endorsed by the Edmond Historical Society, supported by the City of Edmond Visual Arts Foundation, further funded by the Edmond City Council and the state of Oklahoma, and had become an 'official Oklahoma Centennial [of Statehood] Project'. 'Having ann [sic] historical woman sculpture gracing our city [will] be most progressive and fitting', declared Life and Leisure. Said Munson, 'Nanette [sic] Daisey personifies so many of the really wonderful characteristics of those who took the chance to settle and develop Oklahoma. She was brave, intelligent and committed. ... The fact that she accomplished so much with the add-itional difficulties associated with just being a woman in those days makes her story even more interesting. ${ }^{3}$

Interesting for feminist historical geographers ${ }^{4}$ as well as other scholars studying the interpretation of the past, however, is the fact that, as I will show, though Daisey did claim land near the original Edmond townsite, she did not jump from a cowcatcher and remove her petticoat to do it. Indeed, as I will show, the canonization of that event into a legendary-storysoon-to-become-monument is the result of some 100 years of superficial scholarship fed by the powerful romanticizing forces of mythic images of the American West and westerners. The legend's repetition in numerous published town histories and the absence of meticulous research led to its acceptance as fact in local lore, and ultimately to the proposal for the monument, while the similarly legendary status of so many western characters left a proposal for such a monument unquestioned, and even gained it broad support. Thus, as I will show, the Daisey monument, planned as part of a progressive effort to include local women in the telling of Oklahoma's history, will, in larger-than-life format, depict an event that never occurred. And that, in itself, is an occurrence that provides an opportunity to set Nannita Daisey's record straight, as well as to examine in greater detail the representation of women in the 19thcentury American West, to consider the stories evoked and the stories silenced by such representations, as we, in ongoing ways, seek to place a more inclusive past in our present.

Put briefly (for I will explore this more fully in a moment), as feminist scholars - geographers and historians among them - labor to include women's lives in the telling of US western history, tales of the lives of women both ordinary and extraordinary have been drawn to the fore..$^{5}$ And, as such tales spread through the world of academia, some also reach a more public audience, often in heroicized accounts of women's lives, ${ }^{6}$ but significantly also in landscape, as monuments to 'women pioneers'. ${ }^{7}$ While most efforts to include women's stories and women's lives in the telling of western history are laudable, as Mike Heffernan and Carol Medlicott encourage, feminist scholars must not stop there. ${ }^{8}$ We must also examine in detail the stories told, the narratives evoked by the telling of such tales, and the implications their landscape renditions have for the creation of American social memory. Indeed, as Mona Domosh and Karen Morin have argued in their call for future work in feminist historical geography, we must show, 'through example, how understanding the historical construction of gendered (and racialized and sexualized) difference is necessary to any work for contemporary social change, and how all historical subjects are gendered ones.' This, as anthropologist Richard Flores has pointed out, can be challenging, but 'When such unpacking brushes up against the production of national or regional myths, icons, memories, and ideologies that have 
contributed to the racialization, stereotyping, and social displacement of others, it behooves us to probe deeply and honestly into regions some would rather leave unexplored. ${ }^{30}$

In a direct effort to contribute to this task, I here examine the life of Nannita 'Kentucky' Daisey, and the proposed commemoration of her in the bronze-and-granite monument planned for downtown Edmond, Oklahoma. Numerous newspaper stories in the 19th, 20th, and 21st centuries as well as book-length histories of the city of Edmond and the state of Oklahoma have chronicled her exploits, so I begin with a synopsis of their rich accounts. But since not all of the commonly accepted story is grounded in verifiable fact, I detail how these narratives about Daisey's exploits became what they are today. Then, exploring the imagery Daisey's tale evokes, I situate the story in the mythology of the American West and the efforts of feminist scholars to document and build a women's western history, as I examine the story's gendered portrayal of (white pioneer) women in the US West. ${ }^{11}$ That, as I reveal, Daisey's exaggerated story resonates with decades-old gendered stereotypes may seem at first blush unsurprising, yet the fact that it does so in the face of other decades-long efforts to make representations of the American West more multicultural, and more representative of the region's diverse history, means that, as Heffernan and Medlicott point out, the work that such landscape representations do, and can do, deserves our attention. ${ }^{12}$

The efforts to build a statue of 'Kentucky' Dasiey in Edmond can be usefully understood in the context of geographical scholarship on the study of monuments. At least since David Harvey's influential 1979 work on the multiple histories and meanings of the Basilica of Sacre Coeur, and Nuala Johnson's important mid-1990s work on monuments and nationalism in Ireland, geographers have made important contributions to understanding the roles and place of monuments in both the past and the present. ${ }^{13}$ Often these works have insightfully traced the 'life' (or lives) of a monument through different eras, richly examining a monument's meaning(s) for different people in different times, in the specific places where the monuments were erected. ${ }^{14}$ While some studies have addressed ancient monuments, ${ }^{15}$ most have focused on monuments built in the 19th and early 20 th centuries - the golden era for monuments to be sure. ${ }^{16}$ Monument building though, continues to be an important part of urban and national identity formation, intimately linked to the ongoing construction of social memory, to the way the past is made meaningful in the present and projected toward the future, ${ }^{17}$ but only a few geographers have found opportunities to examine monuments as they are being constructed. ${ }^{18}$ Further, while one of Johnson's first calls was to explore issues of gender, few scholars have actually done so in detail. ${ }^{19}$ In fact, as Lorraine Dowler, Josephine Carubia and Bonj Szczygiel point out, 'the study of landscape as it relates to gender', in this case the monumental landscape, is a largely overlooked topic. ${ }^{20}$

In Edmond, Oklahoma, the effort to erect a statue depicting Nannita Daisey's supposed exploits is still today ongoing; the place of the past in the present is not yet secure. This article, built on archival research in local, regional, and national newspapers as well as local historical archives and locally published town histories, on correspondence and interviews with Edmond historians and those involved in the statue, as well as site visits in and around Edmond, represents one effort to engage such processes of memorialization as they occur, and to, following the advice of Domosh and Morin, ${ }^{21}$ bring understandings of gender (and difference more broadly) further to the fore in historical geography. In the final section of this article, then, I explore the implications of what I understand as a gendered spatial framework for understanding and creating social memory in the US West. 


\section{Oklahoma land runs and the 'Kentucky Daisey' story}

Like all land in the United States, the land in the contemporary state of Oklahoma (which means 'Red People' in Choctaw), originally belonged to Native American tribes, including, among others, the Osage, Tawakoni, Tawehash, Wichita, and Yscani. Beginning in the 1830s, when EuroAmerican encroachment was increasing pressure on Native lands in the Eastern and Midwestern US, the federal government vacated previous treaty agreements with the Indian tribes in those regions, and ordered the removal of those tribes in a series of forced migrations that included the infamous 'Trail of Tears'. Indians from across the country were forced to move to lands the government had now specifically set aside for Native settlement. 'Indian Territory', as much of contemporary Oklahoma was then known, was to be a 'uniquely Indian area' perpetually free of white settlement where the Five Tribes removed from the Southeast (the Cherokee, Chickasaw, Choctaw, Creek and Seminole) would live in designated areas alongside several tribes forcibly removed from the Northeast (including, among others, the Fox, Ottawa, Pottawatomi, Sauk, and Shawnee), still others removed from the Midwest (including, among others, the Iowa, Kickapoo, Pawnee, Peoria, and Ponca) and among the other tribes who already lived in the area. After the end of the American Civil War, however, the US government forced the tribes in Indian Territory into new treaties under which they had to cede some of their once-granted lands back to the government. In particular, a two-million-acre area in the middle of what is now the state of Oklahoma called the 'Unassigned Lands' (because, unlike other parts of Indian Territory, they had not then been set aside by the US government for a particular tribe) returned to federal control. Beginning in the 1870s, railroad companies (whose rails traversed the Territory) and prospective white settlers called 'boomers' pressured the US Congress to officially release the Indian lands, especially the Unassigned Lands, to non-Indian settlement. In 1889, the Unassigned Lands were opened under the Homestead Act of 1862 in the first of Oklahoma's now-famous (non-Indian and predominantly white-settler) land runs. What followed was a series of land seizures and reallocations (where eventually even the lands once set aside in perpetuity for specific Native American tribes were redistributed, either by run or by lottery, primarily to whites), ushering in a flood of new non-Indian settlers and culminating, in 1907, in the formation of the state of Oklahoma. The government-mandated "land of the "Red People," as Oklahoma historian Angie Debo wrote, 'was to become the frontier of the white man'. 22

With so much interest on the part of boomers (who stood to gain from the 'free' lands), and in order to grant all eligible non-Indian homesteaders an allegedly equal opportunity to file land claims, government surveyors had first surveyed townsites and 160-acre homesteads across the Unassigned Lands. In a dramatic move, at noon on 22 April 1889, all four borders of that territory were thrown open to any qualified person who wished to claim either a town lot or a homestead. Under the Homestead Act women and men of at least 21 years of age who were US citizens (or immigrants who had filed for citizenship) and who were also either single or heads of households, could claim 160 acres of land provided they paid a small fee, lived on the land, and made 'improvements' over a period of five years. But in Indian Territory boomer publicity had attracted so much attention that many more people attempted to claim land than there was land available to claim. Thousands gathered at the borders (and some, called 'sooners' snuck in - despite the presence of armed troops - before the official 
opening). When the much anticipated signal was given an estimated 50,000 people entered the Unassigned Lands: they ran, walked, rode horses, drove Conestoga wagons, carts, and carriages, or rode on the jam-packed rail cars of one of the four rail lines that already traversed Indian Territory. ${ }^{23}$

Neither was the press oblivious to the excitement. Reporters had been sent from around the country to cover the opening, and, in fact, on the first Santa Fe train headed north into the Unassigned Lands the very front car had been reserved specifically for members of the press. With prime access and 'free land' beckoning, some of the reporters sought to do more than just report. One of those was Nannita Daisey. Daisey, dispatched prior to the land run by the Dallas Morning News, was already familiar with the Unassigned Lands, and had already scoped out a place to make a land claim of her own. Knowing the train would not stop as it passed through the territory, but that the requirements for staking a claim were few, she planned to make her own claim on an uphill grade (when the train would be moving most slowly) by jumping from the moving train, hurriedly driving her claim stakes, and re-boarding before the rear coaches had passed her by.

About this much of the story there is general agreement, but about the details of how Daisey jumped from the train and how she staked her claim there is no such consensus. I begin, then, with the version as told in books about Edmond's history ${ }^{24}$ - the version that will be depicted by the monument.

Desiring every advantage in the crowded rush for land, Daisey convinced the engineer to allow her to ride on the train's cowcatcher at the locomotive's very front, and, holding on for her life, she rode the cowcatcher until the train approached her would-be claim site. Then, by prearranged signal from Daisey, the engineer slowed the train and Daisey leapt free. Scrambling to a spot of vacant land she drove two stakes with her name on them into the ground. Noticing the train's speed was increasing, she hurriedly removed her petticoat, tied it to a nearby bush so she could demonstrate she'd made improvements on her claim, and then fell to her knees, firing her revolver in the air to proclaim her new acquisition. Then, rushing back for the still-moving train, she made it in time to re-board the last car. ${ }^{25}$

With this deed, Daisey became one of the first women to claim a homestead in the newly opened territory, and, told like this, this event has gone down in the history of Oklahoma, and in the history of the town Edmond, on the outskirts of which Daisey's homestead site lies. Indeed, told in this way, the story has been published in numerous newspaper articles as well as in books on the history of Oklahoma, of the Land Rush, and of Edmond itself. ${ }^{26}$ And this is the way Daisey's story will be represented in the commemorative statue, now under construction and slated to debut in downtown Edmond's new Festival Marketplace on 4 July 2007 as the crowning contribution of the city of Edmond to events celebrating Oklahoma's Centennial of Statehood.

But despite the prevalence, and current apparent dominance, of this version of the story, this is not the way Nannita Daisey's story has always been told, and, importantly, neither is it the way Nannita Daisey herself related the events. The discrepancies are significant, and bear investigation, for they not only allow Daisey to speak for herself of her own deeds (as feminist scholars have labored in so many other cases to do), they also, more broadly, help illuminate issues of gender and commemoration in the American West. 


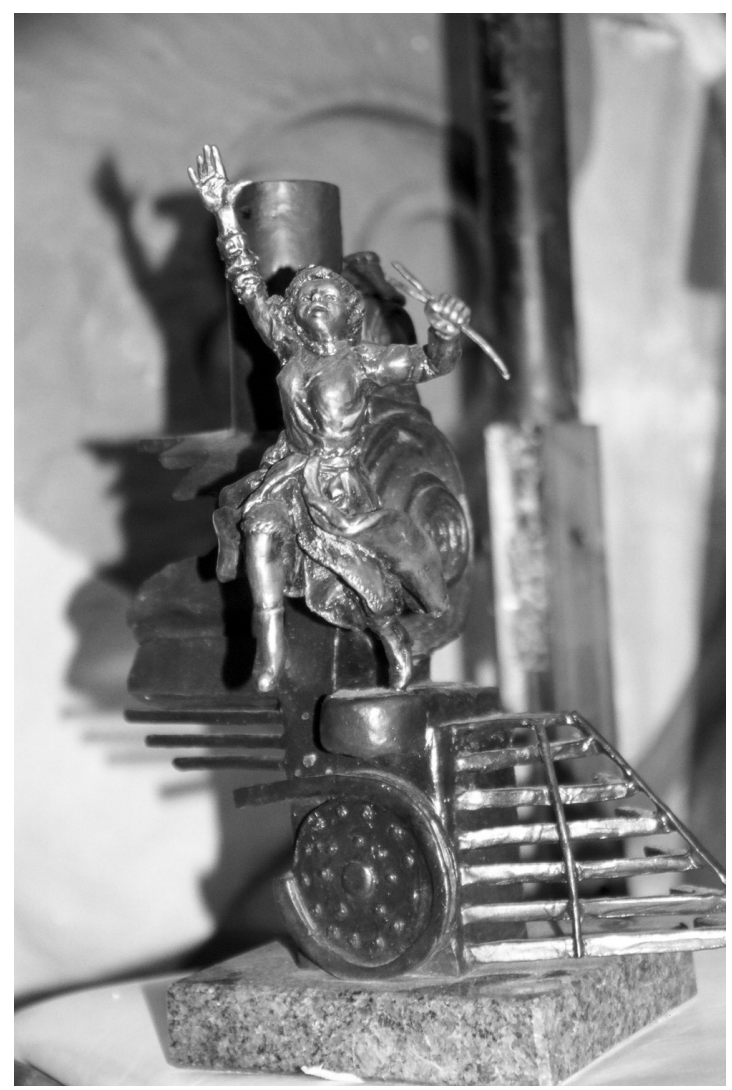

FIGURE 1 Rendering of the proposed monument to 'Kentucky Daisey' now scheduled to be unveiled in Edmond, Oklahoma in 2007. The sculpture, titled 'Leaping into history' was designed by local artist Mary Lou Gresham. (Photograph by the author.)

The only published eyewitness account of Daisey staking her claim came from a fellow journalist, the man who pulled her back aboard the train. He wrote, in the Dallas Morning News that,

One of the earliest boomers to secure a homestead was Miss Nanitta [sic] Davis [sic], ${ }^{27}$ The News' correspondent at Guthrie. That energetic specimen of animated femininity traveled with me into Oklahoma on the first train that went north into the territory after the opening. The train was running about twenty or twenty-five miles an hour all along, but when we came to an up grade where the speed was somewhat slackened my sharp-eyed companion, taking a liking for the section of land through which we were passing, jumped off the platform [the flat boarding area at the passenger coach's ends] near the head of the train, ran across the ditch into the property she coveted, stuck up a pole over which she threw her cloak, fired a couple of shots into the air, and hustling back caught the rear end of the train. I helped her off, went with her and helped her back onto the train. ${ }^{28}$

Daisey herself did not go on the record in a published account for several years after the event. Reflecting back, she related the story to a reporter like this:

I stood in with the engineer. I know my business. ... You see, I'd been in this Territory a good deal, and I had a good claim picked out ... just alongside the railroad. I got on the first train the day it was opened - got on 
the engine. Jiminy! but it was exciting; and wasn't there a lot of 'sooners', too! ... I began to get afraid that somebody would get there before me. When I got in sight of my claim I gave the engineer a signal. He began to slow up. Nearly everybody on the train had heard about me, and I tell you there was excitement. It was intense. I got all my things ready. I had my cloak, a revolver and my two claim stakes with my name on them. When I got even with my claim I gave a jump while the train was in motion. The engineer, you know, did not dare stop the train still. I landed feet first, you can bet your life, while everybody in the cars yelled 'Hurrah for Nannita Daisey!' As the train went by I planted my stakes, threw my cloak over one, then fell on my knees and discharged my revolver in the air exclaiming: 'Thus I salute the Kentucky Daisey's claim!'29

And so, with no mention of either a cowcatcher or a petticoat, Daisey's story began. And thus, two of the most compelling details of the story are either false, or simply not mentioned by the only known published eyewitness accounts, and this raises a number of even more compelling issues about the commemoration of women in the American west. To explore those more fully, we must first understand with more precision how Daisey's story evolved.

\section{In Oklahoma's land runs}

If Daisey's exploits seem extreme, actually they were not. Newspapers of the period covered the activities of land-hungry prospective settlers in great detail, and today provide a context for Daisey's actions. Women boomers like Daisey, because they were engaged in activities not typically expected of women in the late 19th century, attracted considerable attention, and others, like Mabel Gentry who rode a 'little black pony at the full jump', or the Kansas widow traveling by 'old fashioned buggy' with babe in arms and child in tow, appeared in the papers as well. ${ }^{30}$ By the time of the 1893 land run one New York Times article contended that 'at no time in the history of the various openings of public land have the women taken such interest as they manifest at this time'. ${ }^{31}$ Indeed, homesteading independently offered tremendous opportunities for women who had not been allowed to claim land for themselves under previous land-allocation measures. Across the US thousands of women filed and eventually 'proved up' their claims: in western states such as Colorado, North Dakota, and Wyoming such women made up 10 percent of homesteaders; ${ }^{32}$ nationally by the early 1900 s single women accounted for some 20 percent of homesteaders, and they were slightly more successful than men in gaining final title to those claims. ${ }^{33}$

Neither were Nannita Daisey's acts themselves - jumping from the train and firing her revolver to announce her claim - that unusual. Guns of all sorts were widely said to be at a premium in the days before the rush. The New York Times reported that 'every traveler is armed to the teeth', while the Dallas Morning News described 'most' passengers on the first northbound train into the Territory carrying 'tents, camping outfits and guns', noting that in Purcell, the train's last departure point before entering the new lands, 'gun stores and hardware stores have been levied upon for all the Winchester rifles and six-shooters and all the ammunition they had in stock, and the demand has not yet been filled'. ${ }^{4}$ Added the New York Times, when the train pulled forward to cross the line the excitement of those onboard climaxed as 'the sound of pistol shots told that the Texans were firing their salute', a salute that became a 'furious fusillade' as the train accelerated into the Territory. ${ }^{35}$ Once inside the Territory (and on the ground), excited land claimers, like Daisey, fired their weapons to announce their claims to others nearby: as the Dallas Morning News reported, 'One 


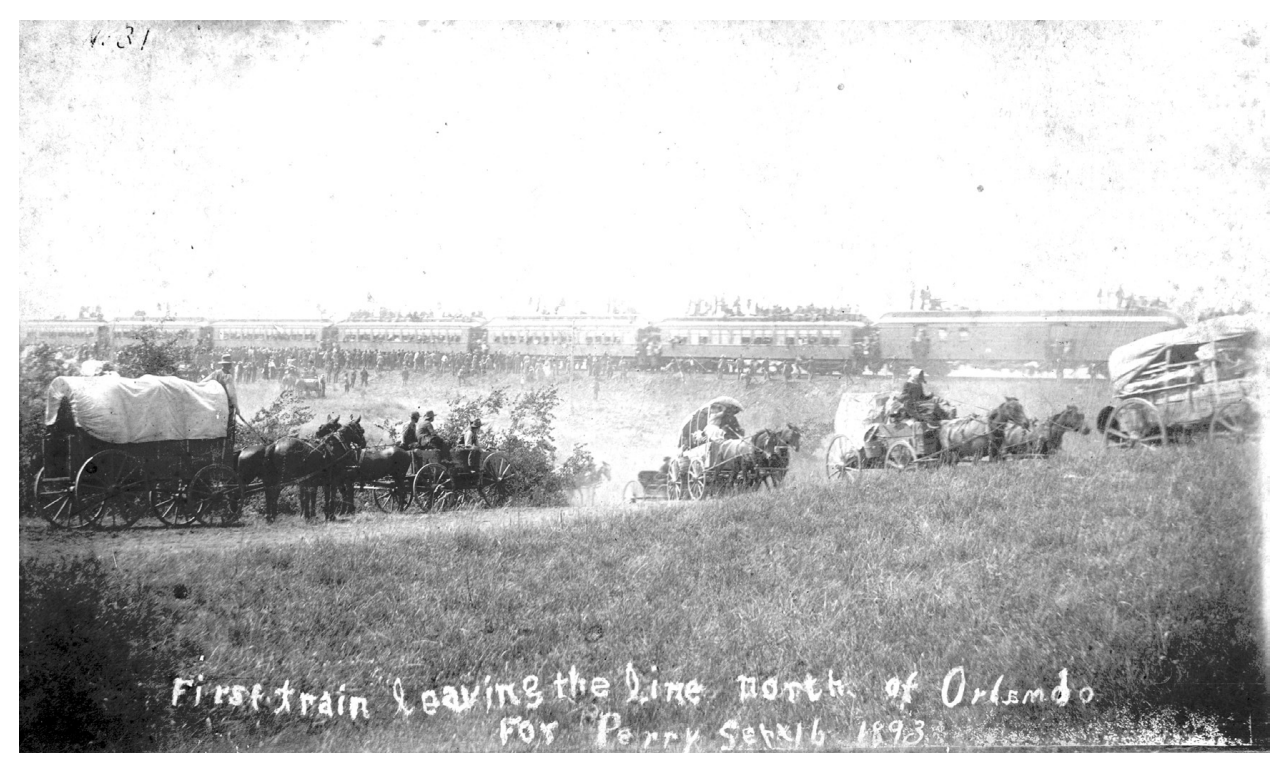

FIGURE 2 Trains, like this one, leading into Indian Territory when new lands were 'opened' to white settlers, were crowded with frenzied, land-hungry whites. Other prospective settlers entered the newly opened lands by wagon, horseback, or on foot, as here at the start of the 1893 land run. (Courtesy Oklahoma Historical Society, Oklahoma City, Oklahoma.)

homesteader who had secured a magnificent quarter section of rolling land ... [made hasty improvements to his claim, but, not] looking upon these evidences of possession as sufficient to confirm his title, he seized a Winchester as the train ran by and fired out all of its contents and then emptied his revolver, yelling like a cowboy or a Comanche Indian all the time'. ${ }^{36}$

Even jumping from the train was evidently not unusual. The trains' coaches were packed the first 12 cars made available on one train were 'crowded with over one thousand people' 'inside of five minutes' - and eager boomers 'filled all of the seats, occupied all of the standing room in the aisles and filled up the space between the coaches, hanging on the banisters and girders with a grip born of despair and determination', on another. ${ }^{37}$ With so much perceived pressure on comparatively little land, it seemed to reporters present that everyone aboard the train 'had a plan whereby he could leave the train after it had passed into [the Territory]'.38 One other journalist, a Mr Rye of Abilene, Texas, began his journey by riding on the brake rod beneath a stock car, only later climbing aboard the car. When he then spied land he desired to claim he leapt, turning 'several somersaults' before finding himself right-side-up. ${ }^{39}$ Others were not so colorfully reported, but seen to be jumping 'from the platforms and the windows of the cars before the train stopped, throwing their spades, bags, and blankets out ahead of them, in their eagerness to stake a claim.... ${ }^{40}$ In fact, in the same article that first reported Daisey's jump, the reporter added that 'there were many similar incidents. All along the route of that train, even when it was going at the limit of its speed, anxious home-seekers could be seen dropping off at various points. ${ }^{41}$

Thus, most of what Daisey was reported to have done was not unusual in general, but it was unusual for a woman to do it. And that, in itself, made her story worthy of reporting. 
Newspapers across the country followed her story and Nannita Daisey became somewhat of a celebrity in the new lands, and to some degree as well, on the national stage. Though exploits such as her dramatic jump are comparatively easy to trace, much of the rest of her biography - as is not unusual for women and members of other under-represented and subaltern groups - is considerably more challenging to unearth, part of what feminist western historian Elizabeth Jameson described as the 'the enormous challenges of western women's history: the methodological, conceptual, and ethical challenges of recovering and bringing into common focus on their own terms the lives of all the women who [have] ever lived in the American West'. ${ }^{42}$ While other scholars have insightfully used sources like diaries, correspondence and oral tradition to gain understanding of women's lives, ${ }^{43}$ Daisey, who left no descendants, also bequeathed no papers to any known person or institution - there are no diaries, no letters, and there is no oral history. What remains is to, as Mona Domosh has done (in her endeavor to understand individual performances of identity in public space through published lithographs), read conventional sources against the grain in an effort to reveal the details of Daisey's life in her own terms. ${ }^{44}$ Available in Daisey's case are census and other government records, as well as newspaper reports - reports that, while they often detail Daisey's exploits in stereotyped patronizing terms and, as do nearly all published period accounts, glorify the non-Indian seizure of Indian lands, also occasionally include interview material and the first-hand observations of Daisey's acquaintances. From these sources I built the following account. ${ }^{45}$

\section{Nannita Regina H. Daisey}

Born in Pennsylvania in 1855 to an Irish immigrant father and a French immigrant mother, Nannita Regina H. Daisey lost both her parents as a child and faced also a separation from her sister, winding up, by age 15, alone at the orphanage of the Sisters of the Good Shepherd Convent in St. Louis, Missouri. ${ }^{46}$ With what one reporter who later interviewed her described as 'more than ordinary ability and education', she moved from St. Louis to rural Kentucky where she became 'the only person, male or female, in the [area] who understood Latin', and gained employment teaching school. ${ }^{47}$ Described by one journalist as 'decidedly pretty' with a 'vivacious way which captured those with whom she came in contact' and by another as a 'trim little figure, the bright eyes, keen as a hawk's, the rapid nervous speech and the tongue that, with all its sharpness ... never said an unkind word of any human being', she was also said to possess 'a spirit of gentleness in her body that endeared her to all those who came in contact with her'. ${ }^{4}$

While in Kentucky she sought work as a journalist in addition to teaching school, but her gender kept her from being hired. Determined, she soon became what the Louisville CourierJournal city editor called 'an irrepressible hanger-on' at the paper's offices, and her 'ready wit and sharp tongue made her a general favorite with the reporters', until eventually 'it was occasionally found convenient to give her an assignment at a wedding, etc' - work thought most suitable for a woman reporter. For more serious stories she was not selected however, until one night when she learned of a 'bad wreck' on a rail line outside of town. Learning as well that no other reporters had yet heard of the accident and that a special train was leaving for the crash site in minutes, Daisey telephoned the editor from the depot, and he agreed to send her only once he realized that 'it would be impossible to get a man' to the scene in time. Daisey 'boarded the special, visited the wreck, gathered all particulrrs [sic] obtainable and then 
walked nearly two miles to the telegraph station to get off her [report], which proved to be a very sensational piece of exclusive news in the Courier-Journal of that morning, ${ }^{49}$

In 1881 Daisey announced her 'candidacy' for the position of Kentucky state librarian, but did not gain the position, despite her earnest efforts to persuade the legislators responsible for the appointment. Supporting herself at that time by teaching, she also gave free lectures on topics such as 'common school education'. Articulate and outspoken, Daisey's 'talent as an elocutionist was both marked and interesting' earning her a reputation in Louisville as " "Miss Daisey" who carried around a license to say what she pleased'. ${ }^{50}$

According to one source, Daisey next moved to Washington, DC where she made enough political connections to secure a teaching position at an Indian school in the far West. ${ }^{51}$ By the time of the first land rush she was evidently no longer teaching but was already familiar with Indian Territory and had already established herself as a correspondent for the Dallas Morning News, known to be "flying around with her notebook and pencil trying to get in a "scoop" on the boys'. ${ }^{2}$

Daisey's efforts (so dramatically reported in the local and national press) to claim a homestead for herself in 1889 did not go uncontested. Upon returning to her claim from Guthrie some days after filing it, Daisey found a Santa Fe engineer named Stafford on the property attempting to claim it for himself. As she later detailed to an interviewer, 'I told him that I'd die before I'd go. He then threatened to shoot me. I told him ... that he would have to put a bullet through my heart and walk over my dead body before he got a foot of that dirt. I tell you I worked for that claim and I'm going to have it'. ${ }^{53}$ Their confrontation may have escalated: by 4 May, just two weeks after she staked her claim, the New York Times reported that Stafford had in fact shot her through the arm. ${ }^{54}$ The Guthrie paper denied the incident, calling the Times report an 'unmanly prevarication'. ${ }^{55}$

Whether shot or not, Daisey did hold her claim, and in fact proved up on it: in the year 1900 she registered the patent on her homestead, described as the 'northwest quarter of section twenty four in Township fourteen north of Range three west of Indian Meridian in Oklahoma Territory containing one hundred and sixty acres, ${ }^{56}$ Photographs from later years reveal the small house she had built on the property (which today no longer stands) (Figure 3).

But Daisey did not confine her activities to her homestead, or indeed to those only in her own direct interests, making also contributions to the new communities of which she was part. Building on her experience as a teacher and her strong belief in public-school education, by the end of May she spearheaded an effort to launch a school in Guthrie, securing a building and enrolling pupils. ${ }^{57}$ Though she did not long teach in Oklahoma, she did remain involved in local schools, serving on a committee to draft school legislation for the first Oklahoma Territorial Legislature in $1890 . .^{58}$

And it was Nannita Daisey who masterminded Guthrie's first 4th of July parade float in 1889, just weeks after the town itself was founded (during the land run). Parading down the new town's main street for a proud Independence Day celebration were cavalry officers, the mayor, the city council, marching bands, fire companies, and representatives of merchants and businesses. But, as the town's paper reported, "it was the "float" in which the people took the most interest. This was the outcome of the genius of Nannitta [sic] R, [sic] H. Daisey'. The float featured local girls 'beautifully costumed in red, white and blue, with the name of the state or territory they represented on their girdles [sashes]' and included one 


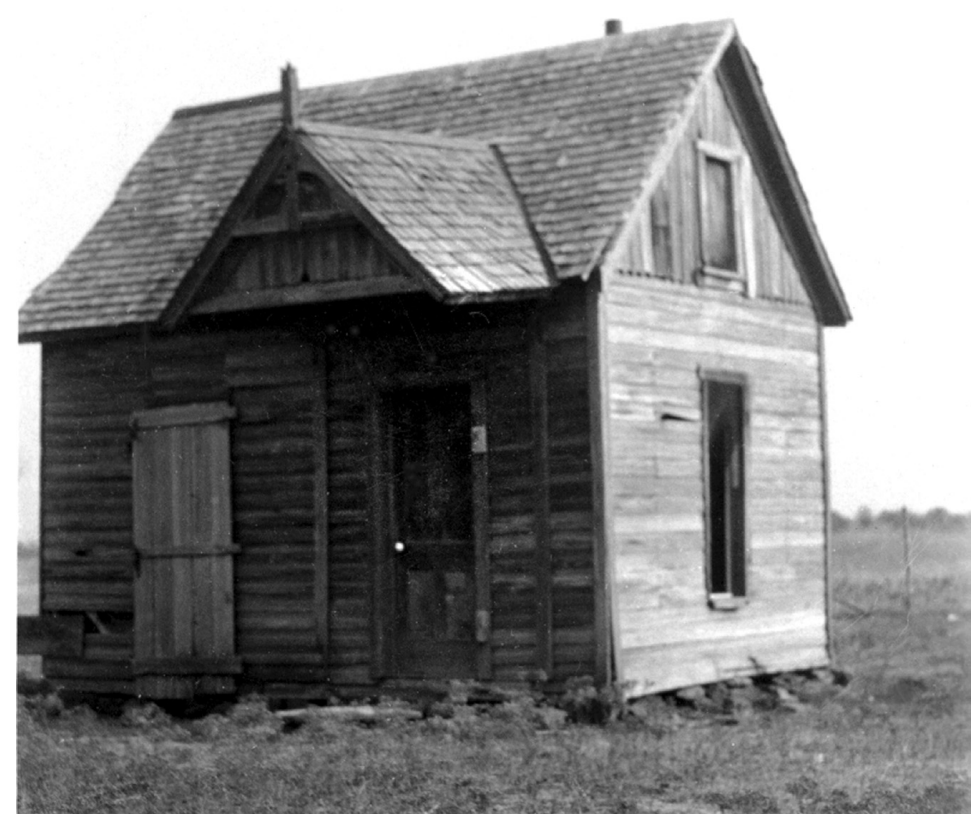

FIGURE 3 The Edmond, Oklahoma home of Nannita Daisey. No known photograph of the house exists for the period during which she lived in it. This picture, taken long after Daisey's death, shows the home abandoned and dilapidated. It was later demolished. (Courtesy Chambers Library Archives and Special Collections, University of Central Oklahoma, Edmond, Oklahoma.)

girl for each of the states of the United States. Atop the float a woman portrayed Columbia the 'Goddess of Liberty' holding a furled American flag in her outstretched arm, reaching and looking towards Nannita Daisey who appeared as 'Oklahoma emerging from barbarism to civilization', her hand, too, clutching the flag (Figure 4). ${ }^{59}$

Because under the Homestead Act, each person eligible to claim land was allowed to claim one homestead (160 acres) and one town-site lot, Daisey was still eligible for more land. On 22 September 1891 she rode a horse in Oklahoma's second land run, this time on the lands that had once been set aside permanently by the government for the Iowa, Sauk, Fox, Pottawatomie, and Shawnee Indians (located just east of the Unassigned Lands), which the US government was on that day officially 'opening' to white settlement. Daisey claimed a town-site lot in the new town of Chandler. Reported thrown from a horse in the mad dash for land, Daisey was said to have been knocked unconscious and even reported killed by one paper, only to later open her eyes and exclaim, "The lot is mine!",60

By the time of the 1892 land run (just west of the original 1889 land run), on lands once reserved in perpetuity by the government for the Cheyenne and Arapaho, Daisey was no longer eligible to claim new property - for herself. Instead this time she led a 'body of eleven female "sooners," all unmarried women ..., ${ }^{61}$ what the New York Times called 'Annetta [sic] Daisy's [sic] Amazons', in order to help them claim their own land. ${ }^{62}$ Hiding in a 'deep gulch' the group hoped to avoid detection until the official opening at which point they would collectively 


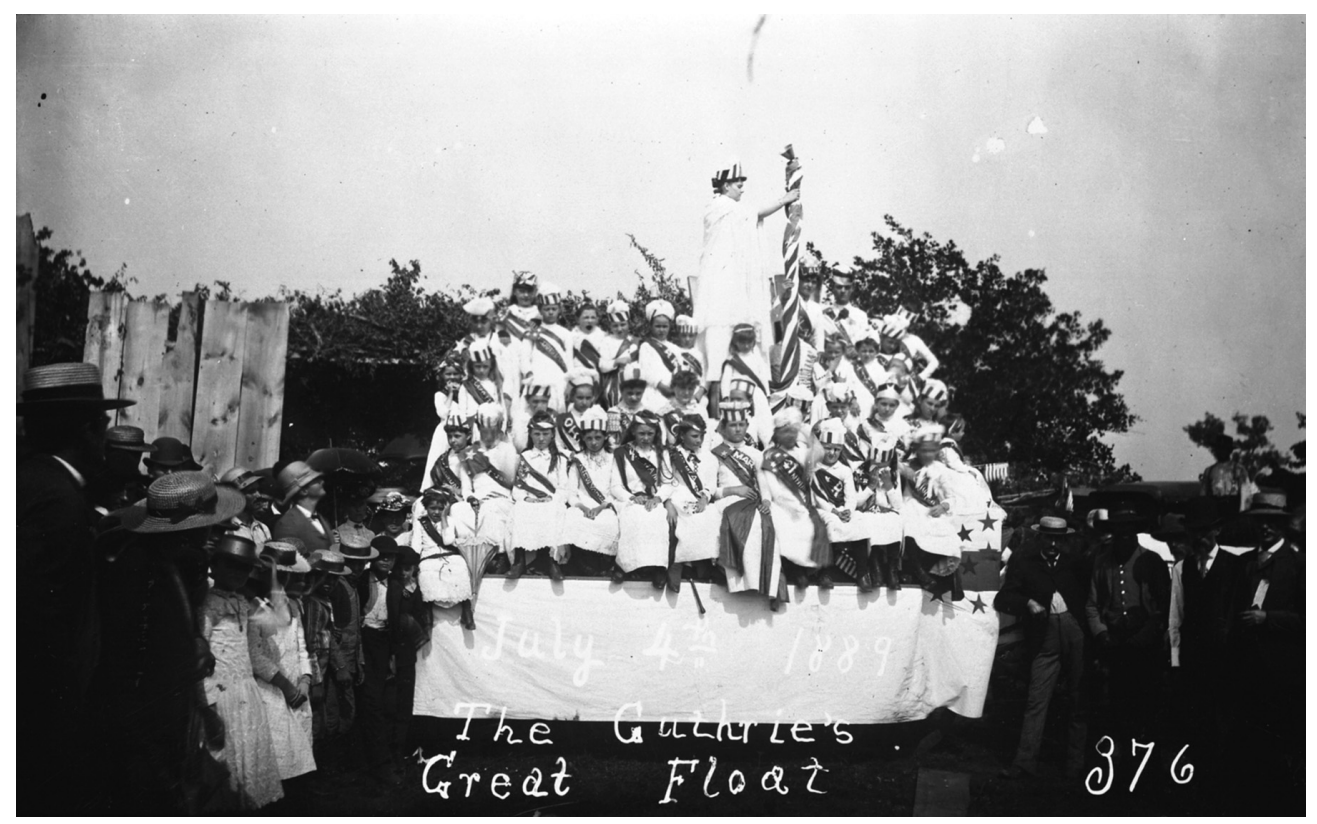

FIGURE 4 The only known photograph of Nannita Daisey shows her appearing as 'Oklahoma emerging from barbarism to civilization' standing just beneath and to the right of the furled flag, facing the camera. Partially visible are the letters L-A-H-O from Oklahoma on her cap. She stands atop a crowdpleasing float she designed for Guthrie's first $4^{\text {th }}$-of-July parade, amidst a group of young girls representing every state and territory in the US at that time, and next to a woman representing Columbia who, with Daisey, holds the American flag. (Courtesy Western History Collections, University of Oklahoma Libraries, Norman, Oklahoma.)

rush for tracts of land which they had (as Daisey had done once before) already selected. Like Daisey herself, the women she led were well educated: the group included graduates of Smith and Monticello colleges. And, like Daisey, each was armed (in this case with rifles and revolvers) and prepared for the horseback dash to claim land. But before the start of the rush Daisey was detained by authorities while on a 50-mile night ride to secure supplies for the group. When interviewed she maintained her confidence in her group's success but, in her endeavors to rejoin the group (making a circuitous 65-mile night ride, guided only, she said, by match light and compass) she was again captured by the cavalry and thus was unable to make the run. ${ }^{63}$ Because she would not divulge the names of those in her group, it is not known if their efforts at claiming land were successful, but no group of women sooners was reported captured. ${ }^{64}$

Two years later, Daisey was still committed to helping other women establish land claims, this time in part of the Cherokee Outlet (to the north and west of the Unassigned Lands), in a run known as the Cherokee Strip land run, on lands once given by treaty to the Cherokee which were later also used by other resettled tribes. This time Daisey was again reported to be the leader of a group of women homesteaders, this time 36 in number, this time legally staking their claims in the largest land run in the United States on 16 September 1893. 
Twenty-two of the 36, the Edmond Sun-Democrat reported half a year later, were successfully working their land together, having already built a residence, planted crops and raised livestock. ${ }^{65}$

Of Daisey's personal life, extremely little is known, or, since she left no heirs and bequeathed no personal papers, even knowable. Despite her evident eagerness to claim Native American land as her own, and her eagerness to help other women do the same, she told one reporter she had once 'had an Indian lover who is now laid away under the sod' and, later, was said to have carried out a valiant and successful clemency campaign on behalf of a 'half-breed' wrongly accused of murder ${ }^{66}$ - apparent contradictions that were not unusual in the 19th-century US. ${ }^{67}$

Further, despite working as an advocate for single-women homesteaders, Daisey herself did not remain single. Scholars studying single-women homesteaders have observed that these women usually did marry, though they generally did so later in their lives than other women. ${ }^{68}$ That is true of Daisey: by 1890, when she would have been 35 years of age, she had married US Army soldier and Scandinavian immigrant Andreas E.J. Ueland Svegeborg. ${ }^{69}$ Ten years younger than Daisey, ${ }^{70}$ local residents told one reporter that the match was an unhappy one, and that he sought transfer to Chicago. In any case, they had no children. Daisey too went to Chicago, it is not known when or why, though one reporter claimed it was to reconcile with her husband who sought divorce. She died there in 1903 leaving no heirs, quite possibly after a divorce. ${ }^{71}$ Her homestead was auctioned the following year in a probate sale, and purchased by another woman, Eurphrasia J. Clayton. ${ }^{72}$

It was after Daisey's death that reports of her exploits took an even more dramatic turn, the turn that will be recognized by the bronze-and-granite monument. After her death, an obituary was published in the Oklahoma City Daily Oklahoman. Under the headline, 'Nanette [sic] Daisy [sic] is dead' the un-credited author wrote that,

The first train that came into Oklahoma from the south on that memorable April 22, 1889, carried as a passenger on the cow-catcher a young woman who was to play an important part thereafter in Oklahoma politics - Nannette [sic] Daisy [sic]. Sitting gracefully on the front end of the engine on that first train, she gave the engineer a pre-arranged signal ... he slowed the train perceptibly, she leaped from the engine and as the train gained a faster motion, she quickly tied her petticoat to a nearby bush and called to the other passengers on the train - 'This is my claim' ${ }^{73}$

Prior to her obituary - the author of which did not quote Daisey herself directly and made no claim to have ever had any contact with her - there had never been, in any account, any mention of a cowcatcher or a petticoat. The only two persons known to have been at the scene of Daisey's claim staking (Daisey and her fellow correspondent) who wrote about the event agreed that she rode the first train, jumping from it - either from the first coach or from the engine - to stake her claim, that she 'improved' her claim with her cloak, and that she boarded the last car of the train before it passed her by. Likewise, the only other accounts from the period closely corroborate her companion's version of the story, describing her jump from the coach platform, with no mention of a cowcatcher. ${ }^{74}$ Furthermore, others who tried to ride the cowcatcher during the run were removed, making it even less likely that Daisey could have prevailed. ${ }^{75}$

Were it so that only the obituary printed the details about the cowcatcher and the petticoat, those details would likely have been forgotten, and Daisey's accomplishments might have 
been remembered for what they were: as a single woman she staked one of the first nonIndian land claims on Native American land in what is now Oklahoma, went on to claim a town lot in a subsequent land run, and then led other single non-Indian women, helping them to establish their own land claims, all the while remaining an active participant in matters and events of local significance. Instead, however, it has been the exaggerations of the obituary that have been passed down in subsequent published accounts of Daisey's life.

Indeed, that version of the story appeared in various newspapers in subsequent years, under headlines like 'Women to fore in Oklahoma', and 'Woman and the land'. ${ }^{76}$ But much more important has been its repetition in books about Oklahoma's history. Oklahoma historian J.B. Thoburn published this version of the tale in his 5-volume $A$ standard bistory of Oklahoma in 1916. ${ }^{77}$ Though Thoburn's book is now out of print, its version of Daisey's story did not fade: journalist Stan Hoig published the exaggerated version of Daisey's claim staking in his (1984) book on the 1889 land rush, as well as in his two books on Edmond's history (published in 1976 and 1987). ${ }^{78}$ Historian James Crowder published it in his own book about Edmond as recently as $2000 .{ }^{79}$ Oklahoma historian Linda Williams Reese published it in her book on the women of Oklahoma in 1997, ${ }^{80}$ as did former journalist Glenda Carlile in her book on women in the Oklahoma Territory. ${ }^{81}$ Thus, the exaggerated version of Daisey's claim staking is the only one published in current histories of Edmond, the land rush, and women in Oklahoma. And unsurprisingly, with Hoig in particular available for interviews, it became, with no voice of opposition, the version published in Edmond's and other regional newspapers throughout the 1980 s, 1990 s and early 2000 s. $^{82}$

This finally raises a perhaps unanswerable question: why did Daisey's obituary and the subsequent reports exaggerate her already dramatic land-claim story? We will never know for certain. But the works of feminist historical geographers and women's historians offer one possible understanding of a perhaps more enlightening question: what does the canonization of the exaggerated version of Nannita Daisey's dramatic claim-staking story imply about the history of women in the American West, the ways they are remembered, and the ways they are commemorated in landscape?

\section{Putting women (and Nannita Daisey) in western history}

Before the late 1970s the history of the US West was told as an ever advancing and largely triumphal westward march of white males. ${ }^{83}$ Women, scarcely mentioned, when they were included at all, were most often presumed to be white and described as what historian Dee Brown famously called 'gentle tamers' - taming social conditions (and, as Joan Jensen and Darlis Miller point out, ${ }^{84}$ their men) after their men had tamed the wilderness. ${ }^{85}$ Thus, women white women and women of color - were long either absent from works about the US West, or, by their rarity, relegated to positions of presumed insignificance: they were not the fur trappers, pony express riders, miners, politicians, railroad builders, or cattle drivers who long formed the central characters of US western history. When white women were addressed, as feminist western historians Jensen and Miller observed some 25 years ago, they were most often made to fit into one of four literary/historical stereotypes, as gentle tamers, sunbonneted helpmates, bad women, or hell-raisers. ${ }^{86}$ 
While such stereotypes clearly obscured, and continue to obscure, the complex realities of western life for women of different ages, classes, and racial and ethnic backgrounds living in different parts of the American West over a lengthy period of time, ${ }^{87}$ and while feminist scholars have long-since gone beyond such crude typologies, for many Americans today the four stereotypes of white western women of the 19th century are still readily recognizable - not because of their accuracy or their purchase on reality, but because they have been perpetuated in (for the most part non-scholarly) literature on the American West - in books, magazine and newspaper articles, as well as in film and on television. Because of this continued popular resonance they bear brief review here. The widespread gentle-tamer image included women as 'civilizers, ladies, and suffragists', often 'pious, pure, and submissive'. More common still than this, according to Jensen and Miller, has been the enduring image of the sunbonneted helpmate who 'carried out routine chores in addition to doing men's work when emergencies arose or their men were away'. In counterpoint to the helpmate, has been the image of the bad woman - these were the prostitutes, the 'soiled doves', and their ever-popular sub-type the 'harlot with a heart of gold' familiar to many American TV viewers as Miss Kitty from 'Gunsmoke'. Most relevant here is the fourth stereotyped image of women, the hell-raiser. Though less common than the others, the hell-raiser, according to Jensen and Miller, drew perhaps the most attention in the popular media: the 'super cowgirls, the Calamity Janes, who acted more like men than women and became the heroes of dime novels and wild west shows'. ${ }^{88}$ Though, as Jensen and Miller pointed out, scholarship in women's western history since the early 1980s has moved well beyond such restrictive and inaccurate images, ${ }^{89}$ as the Nannita Daisey legend and the monument soon to be unveiled demonstrate, in popular culture, and importantly in landscape, such stereotyped images of westering women stubbornly persist.

That such legendary figures as Nannita Daisey (and many others with exploits even more 'grand') should arise, however, should be no surprise, for as scholars of the US West have pointed out, for more than 100 years, the American West has been 'the most strongly imagined section of the country' existing as a physical region but equally importantly as a mythic place where such values as independence, self-reliance, and high moral character are glamorized and portrayed in stark relief. Westerners, mostly male but also female, mostly white, but also people of color, have long been widely mythologized. ${ }^{90}$

This mythologizing of the West, and of (white) westerners, while it is perhaps most wellknown to us from its 20th-century expressions, began in the 19th century, even while many of the subjects of mythologized accounts were still living. Indeed, during the 19th and early 20th centuries, the mythic West and its cast of characters grew along with the ongoing EuroAmerican conquest of the region. Stories of real characters and their real actions in real places were conveyed to (white) American audiences in heroicized terms. And those stories came to be understood as heroic because of the region they took place in, as (white) Americans drew glamorous accounts from the dispossession and subjugation of others. Over time, the two (the region and its mythologized stories) became understood as mutually constitutive, each relying, in (white) American accounts, upon the other. ${ }^{91}$

Significant here is the work of 19th-century 'frontier' journalists who competed against one another to secure not just scoops but also compelling stories. In a time before radio and television, western journalists like Daisey, along with those today better known like Mark Twain, Dan DeQuille, Bret Harte, and 'Lying Jim' Townsend, were often more concerned with telling 
a good yarn than factual accuracy. Coloring their reports with hyperbole, exaggerated claims about western happenings like the Oklahoma land runs were not unusual. ${ }^{92}$ For example, the story of Mr Rye the reporter from Abilene, seems to have been retold by another reporter, and this time, instead of Rye rolling to a stop on the ground, his somersaults were aerial: 'a tall, lank Texan ... tumbled out of a car window, hatchet and stakes in hand, turned two or three somersaults in the air, finally gained his feet, and then began frantically driving a stake in the center of the railroad track ...? ${ }^{93}$ Such tales sometimes circulated about Daisey as well, and even the exaggerations could become news items. In the case of her 'death' at Chandler, a local paper sarcastically protested the exaggerated account, writing that 'Miss Daisy, who was run over and "killed at Chandler" during the rush for town lots, was killed again last week at El Reno by being thrown from a carriage. Four Doctors finally brought her to life again and now she is as alive as ever, ready to be killed once more'. ${ }^{94}$ Such accounts, with their exaggerated details and untraceable sources proliferated, until they became part of what was expected of western reporting, and of westerners themselves, helping to shape the way the mythic West would be understood by readers and by writers, as well as by those the articles portrayed. ${ }^{95}$

Often, in fact, the mythologizing of (mostly white, mostly male) westerners was so compelling that 19th- and early-20th-century westerners worked to fit themselves into their mythologized images. New Western Historian Richard White, for example, describes how soldier and Indian agent Kit Carson once found a book chronicling his heroic exploits on the scene of a murder he had been unable to prevent, and thus found himself falling short of his own mythologized portrayal. ${ }^{96}$ Similarly, lawman Wyatt Earp, famous for what has become known as the gunfight at the OK Corral in Tombstone, Arizona in 1881, outlived most of his 19th-century contemporaries, and labored to construct his own reputation, befriending Hollywood luminaries like Tom Mix and John Ford, and influencing the direction not only of his own mythologized portrayal but also of film westerns more broadly. ${ }^{97}$ Indeed, by the early 20th century, movie westerns were actively creating the mythic West, often with help from those like Earp who had played 'original' roles. Former Marshal William Tilghman, for example, when directing the 1915 movie 'Passing of the Oklahoma outlaws' heard of a double bank robbery in a town nearby their filming location and rushed to the scene, resuming his role as Marshal to arrest the three robbers, only to return to his director's chair to have the three outlaws filmed for an insert shot in his picture. $^{98}$

Nor were women excluded from such compelling and competitive mythologizing. Beginning in the 1870s, Martha Canary, better known by her nickname 'Calamity Jane,' drew publicity wherever she went and left a trail of newspaper articles, dime-novel stories, and eventually even movies and television programs that have consistently exaggerated her accomplishments and altered her biography, claiming, for example that she was a pony-express rider, stage-coach driver and frontier scout as well as a gun-toting paramour of 'Wild Bill' Hickock and frontier Florence Nightingale. In truth, she was none of those (except gun-toting), but her own dictated autobiography, published in 1896, did nothing to dissuade readers or future writers. While, as with Nannita Daisey, Canary's legend increased after her death, her own words published during her lifetime, served similarly only to bolster her mythic reputation. ${ }^{99}$

Neither were gunfighters, lawmen, and other compellingly colorful characters the only westerners who labored to mythologize their own images in line with the increasingly popular 
mythic western stereotypes. In fact, Elinore Pruitt Stewart, a single-woman homesteader whose articles describing her experiences were published in the Atlantic Monthly and later in book form - making her nationally known and endearing her and her travails to thousands of readers - chose not to reveal her marriage (which took place just days after filing on her claim) until long afterward. In Pruitt's case, she later wrote that even after her marriage she wanted the challenge and the accomplishment of homesteading on her own (though she lived with her husband, and it was he who built her cabin as an addition to his own), and acknowledged that she had been somewhat 'ashamed' of the perceived impropriety of a marriage made in haste and out of convenience. She also later relinquished the claim (though the land remained in her family), but never publicly acknowledged the relinquishment. In print, she remained the romanticized image of the single-woman homesteader, one she herself helped to make famous. ${ }^{100}$

Daisey's case is quite similar, though since she left no known correspondence (published or unpublished) we are left to speculate on her motivations. Like Stewart, Daisey married not long after claiming her homestead. In fact, Daisey married before proving up on her original homestead claim, before even filing on her town-lot, and before leading other women to claim their lands. Similar again to Stewart, none of the articles about Daisey's land-run exploits mention her marriage. Actually of course, the marriages themselves are not unusual: particularly in the arid West where successful homesteading was most often a family challenge rather than an individual undertaking, women homesteaders most often did not remain single. ${ }^{101}$ But the mythology of the West that already led so much of what was reported about westerners seems to have compelled Stewart to write about herself, and others to write about Daisey, as if both women were still single.

But though Daisey published no correspondence, she did leave an indication of her own desire to be remembered heroically. After establishing her homestead claim in the 1889 run it was apparently Daisey herself who sent word to the press that engineer Stafford had shot her, reportedly wiring from the depot the following message:

Miss Nannitta [sic] Daisey, the brave little woman who secured a claim near Edmond, was shot in the arm to-day by an infuriated railroad man, who tried to order her off her claim, saying that the land was his. He shot to kill, but she threw up her hand and received the bullet in the forearm. Much indignation is expressed here over the event, and threats of lynching are heard. ${ }^{102}$

Thus, Daisey's story, like that of Elinore Pruitt Stewart, 'Calamity Jane', and so many other westerners, was colored both in its portrayal of what she did, and who she was by powerful mythologizing of the West and westerners. As one reporter wrote of her, 'Miss Daisey presents in her personality one of the most eccentric and inexplicable characters in which the west is supposed to abound'. ${ }^{103}$ Importantly, Daisey herself was - like Stewart and Calamity/Canary - at least at times, the originator of such mythologized portrayals.

Since tales such as those of Carson, Earp, Tilghman, Pruitt, Calamity/Canary, and Daisey along with hundreds of others both legendary and genuine - have reached broad audiences over a prolonged period of time, mythic-western imagery has become difficult, even for scholars, to transcend. In fact, some of the same scholars who have labored to enrich US western history by bringing the lives of women and people of color previously so often overlooked to the fore, have done so within the stereotyped mythic-western models. ${ }^{104}$ But for those scholars who have endeavored to move beyond the stereotypes, the very inaccuracies 
of such representations have revealed the limits of the formerly well-established historical frameworks that shaped interpretations of the heroic westward-moving white-man's frontier and the people who came to live there.

Feminist western historians, for example, have shown how the common stereotypes of western women served as the female counterparts of mythic-western men. 'Across all racial and ethnic groups', Jameson points out,

the stock stereotypes divided women into good women and bad, all of them judged wanting by the histories that generated them. ...

The stereotypes inhabited a public masculine territory that offered no way for women to win. The good women were not man enough for the West. The best stayed hidden in domestic seclusion, far from the public arenas where history was made. Those who, like good men, were sexual, competent, self-reliant, active, and adventurous became, by definition, bad women. ${ }^{105}$

In Nannita Daisey's case, from the moment she jumped from the train her exploits were chronicled by others; the notoriety of her first deed made virtually all else she did worthy of reporting. Even a break-in at her Guthrie home was reported in the papers. ${ }^{106}$ But while (white) male characters in tales of the mythic West were hyper-masculine figures, ${ }^{107}$ Daisey would be slotted into one of the stereotypes of a western woman. Portrayed as an adventureseeker, a journalist and single-woman homesteader, Daisey fit not the gentle tamer, the sunbonneted helpmate, or the soiled-dove images, but her gun-toting determination described well the hell-raiser. Indeed, articles about her exploits also often found need to describe her personality, and describe it in ways far divergent from more common gender norms such as the Victorian cult of true womanhood popular during Daisey's lifetime. ${ }^{108}$

Even during her lifetime, the eye-witness account of her claim staking had called her 'that energetic specimen of animated femininity', and other contemporary accounts called her 'plucky', ${ }^{109}$ 'irrepressible'110 and 'fearless'. ${ }^{111}$ Reporters emphasized her outspokenness, portraying it as reckless, and describing a wildness of character. As early as 1889 one article described her this way: 'She will say a good many things to make conventional people stare and if she has two pistols and anybody attempts familiarity on the strength of her conversation she will probably shoot him in a way to make it the most sensational killing in the territory'. ${ }^{112}$ A few years later her reputation had in no way altered: 'The known character of [Daisey] would prevent any man who has resided in the Territory any length of time from forcing his attentions upon [her group]'. ${ }^{113}$ By 1892 when Daisey was a veteran of multiple land rushes a feature story (quoted also above) circulated about her, describing her alleged personality in detail. Headlined, 'Happy in adventure: Strange preferences of a woman', the article continues,

Among the few women who have been heralded by the press as braving the wilds of the newly opened lands in Indian Territory and enduring the discomforts of a semi-civilization, Nanneta [sic] Daisey again comes to the front. ...

Miss Daisey presents in her personality one of the most eccentric and inexplicable characters in which the west is supposed to abound. ... Her life in [Kentucky] was in every way unique and unusual. [As a school teacher in Oldham county she] soon tired of the humdrum life. ... [H] ampered by many eccentric traits of character [she] was by nature a thorough Bohemian. 
... A veritable cowboy in her mode of life and restless wanderer by disposition, she always mingled with every movement of an exciting nature. ${ }^{114}$

By the time of her obituary in 1903 her textual reputation was well established, and the obituary's author described her as 'an eccentric character'. 115

Representations of Daisey in contemporary newspaper accounts, of course, likely reveal more about the gendered constructions of the mythic West than they do about Daisey's actual personality, or even her accomplishments - as feminist historians and historical geographers have pointed out, archival sources on subaltern and underrepresented people invariably reveal much about the time, place, and context in which they were created. ${ }^{116}$ Soon, the monument that will represent Daisey's fictional leap from the cowcatcher will demonstrate that those same mythic constructions of gendered identities still have public purchase - enough, in this case, to raise substantial funding from public and private sources in the Edmond community for what will become Edmond's largest piece of public art, and enough that the proposal for the statue faced essentially no local public opposition. ${ }^{117}$

Beginning in the 19th century, and lingering in popular accounts still today, white 'frontier women' like Daisey have been understood according to stereotyped roles for (white) western women; ${ }^{118}$ Daisey, despite her work as school teacher, journalist, and a leader of other women, has been and likely will be remembered as a 'hell-raiser', and remembered in exaggerated accounts of her life and her accomplishments, with her own motivations and her own accounting of her life missing from the tale. As Elizabeth Jameson has pointed out about women in the West (white women, black women, immigrant women, Native Americans, Asians, and the women of northern New Spain), traditional accounts of US western history 'subordinated the intimate details of reproduction, kin, adaptation, and survival that anchored [women's] lives' and forced them into stereotyped accounts. ${ }^{119}$ In Daisey's case, soon the statue will fix that tale in bronze and granite.

\section{Conclusion}

Monuments, of course, are not simply innocent markers of past people and events. Like other components of social memory they make a version of the past meaningful for the present, and, because of their permanence, cast it forward for those yet to come. As Kirk Savage has written, 'In the future, our commemoration of history and our history of commemoration' will play important roles in determining just what that future will become. ${ }^{120}$ So too, the monuments we choose to build today will influence future interpretations of our past, and thereby help shape the lives of those yet forthcoming. In the near future, the Nannita Daisey monument will be unveiled in Edmond, Oklahoma's festival marketplace. Intended as a progressive attempt to include women among the ranks of Oklahoma's 'pioneers', by depicting a heroicized event that never occurred it will also, albeit perhaps inadvertently, perpetuate the stereotyped images of those very pioneer women, and continue to obscure the perspectives and histories of the Native Americans to whom Oklahoma belonged. As Marita Sturken has advised, 'we need to ask not whether a memory' or, in this case a story about the past, 'is true but rather what its telling reveals about how the past 
effects the present'. ${ }^{121}$ In this case, as New Western Historian Patricia Limerick observed more than 10 years ago, despite efforts (by New Western Historians and also, I would add, by feminist historians and historical geographers) to make our understanding of the American 'frontier' more inclusive and multicultural, to move beyond the concept of a westward-moving white-man's frontier to embrace the contributions made by women, Native Americans, African Americans, Hispanics, and Asians amid the 'legacy of conquest', popular images of the frontier and the frontier experience have been slow to change. ${ }^{122}$ Fully incorporating the stories of women, and of 'the many peoples who have lived in what is now the American West,' as Jameson has pointed out more recently, continues to be an ongoing challenge. And, as the Nannita Daisey monument makes clear, 'a history that fully integrates the women of the American West remains in the process of creation.' ${ }^{\text {,23 }}$

I have, in this article, attempted to take the advice of Mike Heffernan and Carol Medlicott, who, studying the narratives evoked by the commemoration of Sacagawea in the memorial landscape of the American West, declared that we must examine in detail the actual stories told, as well as the narratives evoked by the telling of such tales, and the implications their landscape renditions have for the creation of American social memory. ${ }^{124}$ And I have tried to heed the call from Mona Domosh and Karen Morin who challenge feminist historical geographers to lend understanding of how all historical subjects are gendered and how the historical understanding of difference is necessary for contemporary social change. ${ }^{125}$ Soon the city of Edmond, Oklahoma will unveil a new piece of public art, commemorating one of its earliest white 'pioneers' not for what she did, but for what she did not do, and thereby celebrating her life according to long-established gendered stereotypes of western women. Nannita Daisey made history in the 19th century by jumping from a moving train to claim Native American land in Oklahoma's first land run, by later claiming a townsite lot, and by still later helping other white women to do the same. She also advocated public school education and served the local communities in which she lived. In the 21 st century her legacy will be cast in stone, commemorating not her actual activities or the futures those activities helped to foreclose, but rather her legendary leap, petticoats flying, from the cowcatcher at the train's very front. Nannita Daisey, so long mythologized in both the local and national press, will take her place in our future as a representative of white women's contributions to glorified land seizure in Oklahoma, but not as the woman she actually was, instead as the legendary figure she has today become.

As Savage has pointed out about other monuments, 'a funny thing happened once a monument was built and took its place in the landscape of people's lives: it became a kind of natural fact, as if it had always been meant to be'. ${ }^{126}$ It seems, therefore, likely that for Nannita Daisey the chance has passed to take her place in history for what it was she actually did. Yet, in this article, I have made every effort to correct nearly 100 years of mis-scholarship on Nannita Daisey's life, and to, in the face of her monument's construction, portray her deeds for what they were, and understand her life in the sociospatial context of the highly mythologized lives of westerners, which, in its own way, provides a backdrop for the statue's misrepresentation.

As Karen Morin and Lawrence Berg pointed out nearly 10 years ago, writing women's stories, voices, and lives into (US) historical geography is an urgent and important project. ${ }^{127}$ And as the story of Nannita Daisey and the monument that will commemorate her makes 
clear, that project remains urgent and important, for despite the earnest efforts of our scholarly work, too little of it has as yet reached a wider public. Historians' and geographers' analyses of the mythic West and its foundational impacts upon American culture and landscape have remained, for the most part, abstract - confined to books, book chapters, and articles. But elsewhere the ideology of the mythic West itself still resonates, continually reminding its viewers through the popular-culture imagery of fiction, film, and television, as well as in landscape representations, of the heroic gendered and racialized characters westerners are thought once to have been. In landscape representations like monuments such mythic abstractions become tangible, providing a spatial fixity for ideas and concepts read about or seen on TV.

More than 100 years after Nannita Daisey's death she will be commemorated on what feminist historians have described as men's terms, according to stereotypes of hell-raising women in the widely mythologized American West. ${ }^{128}$ As Jameson has pointed out, examining 'such one-dimensional stereotypes' has enabled scholars to highlight 'the assumptions and the plots that reduced women to distorted caricatures. Getting past the stereotypes [has] required multi-dimensional actors whose lives raised more complex issues than either/or questions about liberation and oppression'. ${ }^{129}$ In fact, like others (both men and women), Daisey strove during her life to portray herself according to the mythic-western, hell-raising model, wiring reports of her own (likely exaggerated) injuries, publicizing her dramatic land-claim efforts, and retaining the image of a single-woman homesteader even after her marriage. Working within the mythic-western model, Daisey strove to succeed on white men's terms, securing claims to a homestead and a town lot, and establishing for herself, at least for a time, a public place in her community. The details of her life, however, begin to reveal a more complex story, one of struggle and loss along with public success; one of a quest for notoriety along with an untraceable private life and unrevealed personal aspirations. Whether or not she succeeded on her own terms we will likely never know, but it seems possible that, could Daisey herself witness the heroically exaggerated portrayal of her leap from the cowcatcher, she might, actually, have approved.

But whether or not Daisey would have approved of the exaggeration, the way her story is told still matters. As anthropologist Richard Flores, in his work on the Alamo and American social memory, has pointed out,

Stories of the past envelop us: they inscribe our present and shape our future; stories of the past are linked to the formation of selves and others in a complex tapestry of textured narratives. Are they real? Perhaps. Are they true? Who can know. But it is their real effects that concern me. ... [For] stories of the past track through us and over us as they provide narrative representations and public imaginaries that help us to make our way through the world. ${ }^{130}$

Further, as Michel-Rolph Trouillot points out in his study of western power and the production of history, the narratives of history set, along with their tales, a 'cycle of silences' that serve as powerfully as what is told to shape social memory and our experience of the past. ${ }^{131}$ In the case of the Daisey statue, silenced are Daisey's real story, the contributions of other women to Edmond's settlement, and any discussion of the fact that Daisey and the thousands of others who rushed to claim land were, in fact, dispossessing Native Americans of their ancestral and promised lands. ${ }^{132}$ In fact, only one of Edmond's official Centennial projects honors contributions made by non-white settlers or Native Americans to Oklahoma statehood, something that could easily be interpreted as perpetuating the erasure of Indians 
in the face of the continued glorification of white settlement - indeed, as Edward Linenthal has pointed out, anniversary events such as this one, often continue unsubtly to celebrate whites' good fortune. ${ }^{133}$

In fact, this is precisely the view that many Native Americans in Oklahoma have taken of the state's Centennial celebration, since statehood was itself a result of the land runs that took away Indian lands. Wallace Coffey, Chairman of the Comanche Nation said of the Centennial, 'It brings back memories of the Land Run and the loss of many acres of our land. We won't celebrate the Centennial, because we can't'. ${ }^{134}$ But neither have Native peoples in Oklahoma been silent about the construction of monuments honoring the Land Run elsewhere in Oklahoma. An official Land Run Monument, currently under construction at the Oklahoma State Capitol and also slated to be completed in 2007 for the Centennial, witnessed protest from Native Americans, who drew public attention to the fact that such monuments serve to obscure Native presence and to mask the injustices that the land runs represent to Native peoples. ${ }^{135}$ In Ponca City, Oklahoma (not far from Edmond), Native Americans have led a campaign to remove a 30-foot bronze sculpture depicting a man on horseback with claim stake about to claim Native lands in the Cherokee Strip land run of $1893 .{ }^{136}$

Intriguing in Daisey's case is the fact that such public protest has been absent. But just as the records of her actual life remain incomplete for the lack of correspondence, diaries, an oral history, or other first-hand accounts of her life, so the public records of her monument's construction reveal only the compelling absence of public protest, not the reasons for its absence. When, at the turn of the last century, white women suffragists sought to bring women into the US monumental landscape and chose, as their icon, the image of Sacagawea, 'an enslaved Native American teenager', they mustered her image to speak on behalf of the subjugation of all her people, and indeed in favor of the cause of US imperialism in the west. In their laudable efforts to bring women further to the fore, they also more deeply inscribed the subjugation of Native Americans. ${ }^{137}$ And now, history, it seems, will repeat itself: in a contemporary effort to recognize women's contribution to the Edmond community, the statue of Nannita Daisey will (again) mis-portray one real woman's actions and life, and (again) glorify white seizure of Native lands. Clearly, then, it is not enough that women, so long underrepresented in the monumental landscape, ${ }^{138}$ simply become a part of that landscape.

Seen from this perspective it becomes clear that the Nannita Daisey monument is not so much a progressive move to inscribe the lives of pioneer women into Oklahoma's memorial landscape (despite the local paper's claims to the contrary). ${ }^{139}$ Instead, the statue will miss an opportunity to commemorate a local woman on her own terms for her efforts in building community, it will glorify land seizure and obscure the experiences of the Native Americans to whom the land belonged before the US government vacated its promises, and it will reinscribe and perpetuate a stereotyped image of western women based upon an exaggerated telling of a real event. That this could happen, and indeed will happen, is all the more reason to, as Heffernan and Medlicott have advised, attend carefully to the stories told by monuments like these, attempting to understand the images evoked, ${ }^{140}$ and, in this case the opportunities missed. The challenge remains, as Morin and Berg articulated, to continue to write women, along with all previously under-represented peoples, in to our stories about the past, as we draw attention to the social constructions of gendered, 'raced', and classed identities, ${ }^{141}$ and, I would add - as we labor to make our own past more inclusive - to understand 
the landscape imprints that such constructions will leave not just for the present, but importantly, for our future.

\section{Acknowledgements}

My most profound gratitude is to a self-described Edmond 'history buff' who first told me of Nannita Daisey and the proposed monument. Encouraging me to write about Daisey as an effort to set the record straight this friend provided expert local knowledge, invaluable research assistance, and helpful comments on earlier drafts of this work. Maria DeLong graciously shared her work-in-progress about Daisey with me, and I mine with her. Thanks to Edmond Parks Foundation President Curt Munson, and sculptor Mary Lou Gresham for their generosity with their time and for sharing their interests in Daisey. Thanks also to Lorraine Dowler, Liz Gagen, Gerry Kearns, and Karen Till, along with editor Mona Domosh and three reviewers, who each provided essential insights, advice, criticism and support.

\section{Bibliographical note}

Dydia DeLyser is Associate Professor of Geography in the Department of Geography and Anthropology at Louisiana State University in Baton Rouge, Louisiana. Her research interests include issues of landscape, tourism, memory, and mobilities, often with case studies in the Western United States. Her publications have appeared in journals including the Annals of the Association of American Geographers, Social and cultural geographies, the Geographical review, and Journal of historical geography. Her book, Ramona memories: tourism and the shaping of Southern California (University of Minnesota Press) was published in 2005. She can be contacted at: Department of Geography and Anthropology, 227 Howe/Russell Hall, Louisiana State University, Baton Rouge, LA 70803, USA; email: dydia@1su.edu

\section{Notes}

1 L. Shearer, 'Parks group seeks statue funding', Edmond Sun (1 July 2002), p. 1.

2 For books telling this tale, see, for example, J.B. Thoburn, A standard history of Oklahoma; an authentic narrative of its development from the date of the first European exploration down to the present time, including accounts of the Indian tribes, both civilized and wild, of the cattle range, of the land openings and the achievements of the most recent period (New York, The American Historical Society, 1916) 5 vols.; S. Hoig, The Oklahoma land rush of 1889 (Oklahoma City, The Oklahoma Historical Society, 1984); S. Hoig, Edmond - The first century (Norman, University of Oklahoma Press, 1987); L.W. Reese, Women of Oklahoma, 1890-1920 (Norman, University of Oklahoma Press, 1997); and J.L. Crowder, Jr., Historic Edmond, an illustrated history (San Antonio, Texas, Historical Publishing Network for the Edmond Historical Society, 2000).

3 The design for the sculpture was selected from competitive entries submitted to the Parks Foundation who all along favored a dramatic rendering of Daisey jumping from the cowcatcher. R. Hibbard, 'Kentucky Daisey stakes claim in Edmond again', Edmond Life and Leisure (25 March 2004), p. 2; L. Shearer, 'Commission's wish list', Edmond Sun (14 December 2005), p. 1; and the Edmond Centennial Commission's website, http://www.edmondcentennial.com/projedmondcc.php (accessed 12 February 2007).

4 As Mona Domosh and Karen Morin point out, despite vibrant work in this area (for examples, see the bibliography of feminist historical geography compiled by Karen Morin and Lawrence Berg at 
http://www.usm.maine.edu/ lsavage/FHG.html [accessed 17 August 2006]), much work in feminist historical geography 'travels' under other names. I here heed their call to label feminist historical geography explicitly as such (M. Domosh and K.M. Morin, 'Travels with feminist historical geography', Gender, place and culture 10 [2003], pp. 257-64).

5 Significant works in women's western history include, S.L. Myres, Westering women and the frontier experience 1800-1915 (Albuquerque, University of New Mexico Press, 1982); S.H. Armitage and E. Jameson, eds, The women's West (Norman, University of Oklahoma Press, 1987); P.N. Limerick, The legacy of conquest: the unbroken past of the American West (New York, WW Norton, 1987); L. Schlissel, V.L. Ruiz and J. Monk, Western women, their lands, their lives (Albuquerque, University of New Mexico Press, 1988); S. Deutsch, No separate refuge: culture, class, and gender on an Anglo-Hispanic frontier in the American Southwest, 1880-1940 (Oxford, Oxford University Press, 1989); P.N. Limerick, C.A. Milner and C.E. Rankin, Trails: toward a new western history (Manhattan, University Press of Kansas, 1991); V. Norwood and J. Monk, The desert is no lady: Soutbwestern landscapes in women's writing and art (Tucson, University of Arizona Press, 1997); E. Jameson and S. Armitage, Writing the range: race, class and culture in the women's West (Norman, University of Oklahoma Press, 1997); V. Ruiz and E. DuBois, eds, Unequal sisters: a multicultural reader in U.S. women's history (New York, Routledge, 1999); V. Matsumoto and B. Allmendinger, eds, Over the edge: remapping the American West (Berkeley, University of California Press, 1999); P.N. Limerick, Something in the soil: legacies and reckonings in the new west (New York, WW Norton, 2001); M.A. Irwin and J.F. Brooks, eds, Women and gender in the American West. Jensen-Miller Prize essays from the Coalition for Western Women's History (Albuquerque, University of New Mexico Press, 2004); and E. Jameson, 'The history of women and the west', in W. Deverell, $A$ companion to the American West (London, Blackwell, 2004), pp. 179-99. Important work by feminist historical geographers on the American West, in addition to Schlissel, Ruiz and Monk; and Norwood and Monk above, J. Kay, 'Western women's history', Journal of historical geography 15 (1989), pp. 302-5; J. Kay, 'Landscapes of women and men: rethinking the regional historical geography of the United States and Canada', Journal of historical geography 17 (1991), pp. 435-52; J. Kay, 'Sweet surrender but what's the gender: nature and the body in the writings of 19th-century Mormon women', in J.P. Jones, III, H.L. Nast and S.M. Roberts, eds, Thresholds in feminist geography: difference, methodology, representation (Lanham, MD, Rowman and Littlefield, 1997), pp. 361-82; M. Cope, 'She hath done what she could: community, citizenship and place among women in late nineteenth-century Colorado', Historical geography 26 (1998), pp. 45-64; S. Craddock, 'Tuberculosis, tenements and the epistemology of neglect: San Francisco in the nineteenth century', Ecumene 5 (1998) pp. 53-80; G. Kearns, 'The virtuous circle of facts and values in the new western history', Annals of the Association of American Geographers 88 (1998), pp. 377-409; K.M. Morin, 'British women travelers and constructions of racial difference across the nineteenth-century American West', Transactions of the Institute of British Geographers 23 (1998), pp. 311-30; K.M. Morin and J. Kay Guelke, 'Strategies of representation, relationship, and resistance: British women travelers and Mormon plural wives, ca. 1870-1890', Annals of the Association of American Geographers 88 (1998) pp. 436-62; and M. Heffernan and C. Medlicott, 'A feminine Atlas? Sacagawea, the suffragettes, and the commemorative landscape in the American West, 1904-1910', Gender, place and culture 9 (2002), pp. 109-31.

6 Titles here include, D.A. Brown, The gentle tamers: women of the old wild West (Lincoln, NE, University of Nebraska Press, 1981, first published in 1958); C.W. Breihan, Wild women of the West (New York, New American Library, 1982); G. Carlile, Buckskin, calico, and lace: Oklaboma's Territorial women (Oklahoma City, Southern Hills Publishing, 1990); A. Seagraves, Soiled doves: prostitution in the early West (Hayden, ID, Wesanne Publications, 1994); E.C. Flood and W. Manns, Cowgirls: women of the wild west (Santa Fe, NM, ZON International Publishing, 2000); and K.E. Krohn, Wild West women (Minneapolis, MN, Lerner Publications, 2005). 
7 See M. Heffernan and C. Medlicott, 'A feminine Atlas?'. Perhaps the most famous is the 'Pioneer Woman' statue dedicated in Ponca City, Oklahoma in 1930. See http://www.ok-history.mus.ok.us/enc/ pioneerwom.htm and http://www.ok-history.mus.ok.us/mus-sites/masnum25.htm (accessed 1 August 2006). Overall there are far fewer statues to women in the US than there are to men; see P.W. Kaufman and K.T. Corbett, eds, Her past around us: interpreting sites for women's history (Malabar, FL, Krieger Publishing Company, 2003).

Heffernan and Medlicott, 'A feminine Atlas'.

9 Domosh and Morin, 'Travels with feminist historical geography', the quote is from p. 263.

10 R.H. Flores, Remembering the Alamo: memory, modernity, and the master symbol (Austin, University of Texas Press 2002), p. xxi.

11 Recent overviews of US women's history include, N. Cott, G. Lerner, K.K. Sklar, E. DuBois and N. Hewitt, 'Considering the state of U.S. women's history', Journal of women's history 15 (2003), pp. 145-63; and G. Lerner, 'U.S. women's history: past, present, and future', Journal of women's history 16 (2004), pp. 10-27; Elizabeth Jameson provides an overview of women's Western history in, 'The history of women and the West'. Heffernan and Medlicott, 'A feminine Atlas'.

13 D. Harvey, 'Monument and myth', Annals of the Association of American Geographers 69 (1979), pp. 362-81; N. Johnson, 'Sculpting heroic histories: celebrating the centenary of the 1798 rebellion in Ireland', Transactions of the Institute of British Geographers NS 19 (1994), pp. 78-93; and N. Johnson, 'Cast in stone: monuments, geography, and nationalism', Environment and planning D: society and space 13 (1995), pp. 51-65. Several books by geographers have explored monuments, though not as their primary focus, see, for example, D. Lowenthal, The past is a foreign country (Cambridge, Cambridge University Press, 1985); W. Zelinsky, Nation into state: the shifting symbolic foundations of American nationalism (Chapel Hill, University of North Carolina Press, 1988); J. Duncan, The city as text: the politics of landscape interpretation in the Kandyan Kingdom (Cambridge, Cambridge University Press, 1990); K. Foote, Shadowed grounds: Americas' landscapes of violence and tragedy (revised and updated) (Austin, University of Texas Press, 2003).

14 See, for example, H.E. Gulley, 'Women and the lost cause: preserving a confederate identity in the American Deep South', Journal of historical geography 19 (1993), pp. 125-41; R. Peet, 'A sign taken for history: Daniel Shays' memorial in Petersham, Massachusetts', Annals of the Association of American Geographers 86 (1996), pp. 21-43; $\AA$. Boholm, 'Reinvented histories: medieval Rome as memorial landscape', Ecumene 4 (1997), pp. 247-72; D. Atkinson and D. Cosgrove, 'Urban rhetoric and embodied identities: city, nation, and empire at the Vittorio Emanuele II monument in Rome, 1870-1945', Annals of the Association of American Geographers 88 (1998), pp. 28-49; B.S. Osborne, 'Constructing landscapes of power: the George Etienne Cartier monument, Montreal', Journal of historical geography 24 (1998), pp. 431-58; J. Bell, 'Redefining national identity in Uzbekistan: symbolic tensions in Tashkent's official public landscape', Ecumene 6 (1999), pp. 183-213; K.E. Till, 'Staging the past: landscape designs, cultural identity and Erinnerungspolitik at Berlin's Neue Wache', Ecumene 6 (1999), pp. 251-83; B. Forest and J.E. Johnson, 'Unraveling the threads of history: Soviet-era monuments and post-Soviet national identity in Moscow', Annals of the Association of American Geographers 92 (2002), pp. 524-7; J. Leib, 'Separate times, shared spaces: Arthur Ashe, Monument Avenue and the politics of Richmond, Virginia's symbolic lanscape', Cultural geograpbies 9 (2002), pp. 286-312; A.L. Burke, 'Private griefs, public places', Political geography 22 (2003), pp. 317-33; C.S. Campbell and S.D. Brunn, 'Differential locational harmony: the Cristo Redentor statue in the Upsallata Pass', Political geography 23 (2004), pp. 41-69; D.C. Harvey, “National” identities and the politics of ancient heritage: continuity and change at ancient monuments in Britain and Ireland, c. 1675-1850', Transactions of the Institute of British Geographers NS 28 (2003), pp. 473-87; and A.L. Burke, 'Private griefs, public 
places', Political geography 22 (2003), pp. 317-33; K. Till, 'Places of memory', in J. Agnew, K. Mitchell and G. Toal, A companion to political geography (London, Blackwell, 2003), pp. 289-301; B. Forest, J. Johnson and K. Till, 'Post-totalitarian national identity: public memory in Germany and Russia', Social and cultural geography 5 (2004), pp. 357-80; P. Gough, 'Sites in the imagination: the Beaumont Hamel Newfoundland Memorial on the Somme', Cultural geographies 11 (2004), pp. 235-58; and K.E. Till, The new Berlin: memory, politics, place (Minneapolis, University of Minnesota Press, 2005).

For example, A. Boholm, 'Reinvented histories'; D.C. Harvey, “National” identities and the politics of ancient heritage'.

16 On the golden era of monument building, see Kirk Savage, Standing soldiers, kneeling slaves: race, war, and monument in 19th-century America (Princeton, NJ: Princeton University Press, 1997). Geographers who have examined 19th and early 20th century monuments include, Harvey, 'Monument and myth'; Johnson, 'Cast in stone'; Peet, 'A sign taken for history'; Atkinson and Cosgrove, 'Urban rhetoric and embodied identities'; Osborne, 'Constructing landscapes of power'; and P. Gough, 'Sites in the imagination'.

17 K. Till, 'Places of memory'.

18 See, for example, A. Burke, 'Private griefs, public places', who insightfully used interviewing and participant observation to understand the struggles around two monuments in Vancouver, British Columbia.

19 Johnson, 'Monuments, geography, and nationalism'. See Heffernan and Medlicott, 'A feminine Atlas'; Burke, 'Private griefs, public spaces', and Burke, 'In sight and out of view', who do examine gender issues and public monuments.

20 L. Dowler, J. Carubia and B. Szczygiel, 'Introduction. Gender and landscape: renegotiating morality and space', in Dowler, Carubia and Szczygiel, eds, Gender and landscape: renegotiating morality and space (London, Routledge, 2005), pp. 1-15, the quote is from p. 1.

21 Domosh and Morin, 'Travels with feminist historical geography'.

22 See J.C. Walker, 'The difficulty of celebrating an invasion', in D.D. Joyce, ed., 'An Oklahoma I had never seen before': alternative views of Oklahoma history (Norman, University of Oklahoma Press, 1994), pp. 15-26, the first quote is from p. 18; and A. Debo, Oklahoma: foot-loose and fancy free (Norman, University of Oklahoma Press, 1949), the second quote is from p. 27. See also G. Foreman, Indian removal: the emigration of the five civilized tribes of Indians (Norman, University of Oklahoma Press, 1932); M.H. Wright, A guide to the Indian tribes of Oklahoma (Norman, University of Oklahoma Press, 1951); R.E. Cunningham, ed., Indian territory: a frontier photographic record by W.S. Prettyman (Norman, University of Oklahoma Press, 1957); A.M. Gibson, The history of Oklahoma (Norman, University of Oklahoma Press, 1984); D.W. Meinig, The shaping of America: a geographical perspective on 500 years of history, vol. II: Continental America, 1800-1867 (New Haven, CT, Yale University Press, 1993); S. Malinowski and A. Sheets, eds, The Gale encyclopedia of Native American tribes (Detroit, Gale, 1998), 4 vols; D.W. Meinig, The shaping of America: a geographical perspective on 500 years of history, vol. III: Transcontinental America, 1850-1915 (New Haven, CT, Yale University Press, 2000); W.T. Hagan, Taking Indian lands: the Cherokee (Jerome) Commission 1889-1893 (Norman, University of Oklahoma Press, 2003); and E. Jameson, 'The history of women and the West'. Though Native Americans were not allowed to claim the land, not all early settlers were white, in fact, even before the land run Indian Territory had 23 black towns, founded by African Americans, mainly freedmen; see for example J.L. Franklin, Journey toward hope: a history of blacks in Oklahoma (Norman, University of Oklahoma Press, 1982) and A.T. Burton, Black, red, and deadly: black and Indian gunfighters of the Indian Territory, 1870-1907 (Austin, TX, Eakin Press, 1991).

23 Foreman, Indian removal; Debo, Oklahoma; Wright, Guide to Indian tribes; Cunningham, Indian territory; Gibson, The history of Oklaboma; Meinig, Continental America; Malinowski and Sheets, Encyclopedia of 
native American tribes; Meinig, Transcontinental America; Walker, 'The difficulty of celebrating an invasion'; Hagan, Taking Indian lands; Jameson, 'The history of women and the West'.

24 See Thoburn, A standard history of Oklahoma; Hoig, The Oklaboma land rush of 1889; Hoig, Edmond: the early years; Hoig, Edmond: the first century; and Crowder, Historic Edmond.

25 Her petticoat (or in better-documented accounts, her cloak) would have represented a tent - a further sign that somebody had claimed that land, and a first indication of improvements being made to the property. See Thoburn, A standard history of Oklaboma; Hoig, The Oklahoma land rush of 1889; Hoig, Edmond: the early years; Hoig, Edmond: the first century; and Crowder, Historic Edmond.

26 Again, see Thoburn, A standard history of Oklahoma; Hoig, The Oklahoma land rush of 1889; Hoig, Edmond: the early years; Hoig, Edmond: the first century; and Crowder, Historic Edmond. Even a recent Edmond tourist brochure mentions the tale and includes the cowcatcher part of the story: 'Visit Edmond' (Edmond, OK, Edmond Convention and Visitors Bureau, n.d., ca. 2004). The house Daisey eventually built on the property has since been demolished; currently nothing marks the spot of her homestead.

27 Accounts of Nannita Daisey's life and exploits, as well as records of her work and deeds, use varying spellings of her name. In this article, in an effort to write her name the way she herself wrote it but in the absence of documents signed by her, I have accepted the version used on land documents (for which she herself must have been present) as a proxy for written documents in which she herself wrote her own name. See, for example, the patent recorded in Oklahoma County (Homestead) Patent Record Book, Vol. 14, p. 246, on 21 May 1900. 'Half has not been told', Dallas Morning News (25 April 1889).

29 'Happy in Adventure', Chicago Herald (2 May 1892), p. 10; reprinted in abridged form in 'She's a remarkable girl', Utica Saturday Globe (7 May 1892), p. 5. Most sources cite the reprint.

30 New York Tribune (17 September 1893) quoted in America: great crises in our history told by its makers, a library of original source, Volume X, (Chicago, Americanization Department, Veterans of Foreign Wars, 1925), p. 24; 'Oklahoma's colonists', Dallas Morning News (20 April 1889).

31 'Women as land boomers', New York Times (7 September 1893), p. 8. This article, though it carries no byline, has been attributed to Nannita Daisey. See Debbie Kindt Michalke, "“Fortunate enough and plucky enough" the unattached women of the Cherokee Outlet', Chronicles of Oklahoma 75 (1997-8), p. 52-69. No further evidence of Daisey's authorship has been found.

32 Michalke, "Fortunate enough and plucky enough"”, pp. 52-69; see also Reese, Women of Oklahoma, who relates tales of other women land boomers, including that of Mattie Beal who won her land in the Kiowa-Comanche-Apache land lottery and later claimed to have received 500 marriage proposals from men less lucky than she.

33 Jameson, 'The history of women and the West'. These were not only white women: in the first Oklahoma land opening 14 single black women staked claims (Reese, Women of Oklahoma). 'Driving out intruders', New York. Times (20 April 1889), p. 1, and Dallas Morning News 'Oklahoma colonies' (22 April 1889). 'Into Oklahoma at last', New York Times (23 April 1889), p. 1. 'Oklahoma opened', Dallas Morning News (23 April 1889). Ibid.

'Into Oklahoma at last'.

'In the promised land', Dallas Morning News (25 April 1889).

'In the promised land', Dallas Morning News (26 April 1889). Jumping from moving trains was common in later land rushes as well: 'Before the train stopped men began climbing out of windows and tumbling from platforms', reported the New York Tribune on 17 September 1893 (quoted in America: great crises in our history, p. 27). 
41 'Half has not been told', Dallas Morning News (25 April 1889).

42 E. Jameson, 'The history of women and the West', p. 189; italics in original.

43 Reviews of such scholarship include, M. Domosh, 'With "stout boots and a stout heart": historical methodology and feminist geography', in J.P. Jones, III, H.L. Nast and S.M. Roberts, eds, Thresholds in feminist geography: difference, methodology, representation (Lanham, MD, Rowman and Littlefield, 1997), pp. 225-37; K. Boyer, 'Feminist geography in the archive: practice and method', in Women and Geography Study Group: geography and gender reconsidered (Women and Geography Study Group, 2004), pp. 169-74; and G. Lerner, 'U.S. women's history'.

44 M. Domosh, "Those "gorgeous incongruities:" polite politics and public space on the streets of nineteenth century New York City', Annals of the Association of American Geographers 88 (1998), pp. 209-26.

45 Two other scholars have constructed well-documented accounts of Daisey's life; see L.E. Underhill and D.F. Littlefield, Jr, 'Women homeseekers in Oklahoma Territory, 1889-1901', Pacific historian 17 (1973), pp. 36-47; and Maria DeLong, 'Oklahoma's rabble-rousing pioneer, sooner, and newspaperwoman - Nannita Daisey', Chronicles of Oklaboma forthcoming (2007). Because newspaper sources of the period are at times unreliable, I have attempted to detail events supported by multiple sources, or by those with first-hand knowledge of Daisey.

46 US manuscript census, 1870, St. Louis, St. Louis County, Missouri, p. 102; US manuscript census, 1880, Carlisle, Nicholas County, Kentucky, p. 18; 'Happy in Adventure'.

47 'Happy in Adventure'; and 'A fair boomer'.

48 'Happy in Adventure'; 'A fair boomer'; and 'Killed in Chandler rush', New York. Times (30 September 1891), p. 1.

49 'The lady boomer's "scoop"', Oklahoma State Capitol, Guthrie, Oklahoma Territory (27 April 1889).

50 'Nanette [sic] Daisy [sic] is dead', Oklahoma City Daily Oklahoman (18 October 1903); 'A fair boomer'.

51 'Happy in Adventure'.

52 'An infant metropolis', Dallas Morning News (6 May 1889, with byline date 1 May 1889). Only one credited byline is known of, but she likely authored other articles as well; see Nanitta [sic] R.H. Daisy [sic], 'The city of Guthrie', Dallas Morning News (30 April 1889), p. 4.

53 'Happy in Adventure'.

54 'It is not a paradise', New York Times (4 May 1889, with byline date 3 May 1889) p. 1.

55 'An unmanly prevarication', Gutbrie Oklahoma State Capital (11 May 1889).

56 'Patent record', Oklahoma County, Territory of Oklahoma, book 14, p. 246, 21 May 1900; 'Administrator's or executor's deed record', (of Daisey-Svegeborg quarter section), book 19, p. 400, Oklahoma County Court House, Oklahoma City, Territory of Oklahoma, 16 January 1905.

66 'Happy in adventure'.

67 Foreman, Indian removal. 
68 E. Jameson, 'The history of women and the West'.

69 Her married name is first mentioned in the Edmond Sun on 7 August 1890; no official record of her marriage exists, for extant marriage records for Edmond and Guthrie do not date back far enough. In 1894 when she filed for final proof on her homestead she was described as intermarried with Andreas E.J. UelandSvegeborg', Edmond Sun-Democrat (14 December 1894), p. 2. According to the First Territorial Census of Oklahoma (Guthrie County, p. 65) he was 25 in 1890.

71 Her obituary appeared in the Oklahoma City Daily Oklahoman on 18 October 1903.

72 Logan County, Oklahoma Territory probate records, recorded on 31 December 1904, in office of Oklahoma County Register of Deeds, book 19, p. 88.

73 'Nanette [sic] Daisy [sic] is dead', emphasis added.

74 See, for example, 'In the promised land', Dallas Morning News (25 April 1889); 'Everything at a Premium', Oklahoma State Capitol (Guthrie, Indian Territory) (27 April 1889), p. 2 (this account refers to her cloak as her 'duster'); and 'An unmanly prevarication'.

75 'The scene at Pond Creek', Dallas Morning News (23 April 1889). Still, in other parts of the US West at other times that was not so rare: British traveler Rose Kingsley wrote that she was invited to ride the cowcatcher in the Rocky Mountains in 1874 (see K.M. Morin, 'Peak practices: Englishwomen's "heroic" adventures in the nineteenth-century American West', Annals of the Association of American Geographers 89 [1999], pp. 489-514).

76 'Women to the fore in Oklahoma', Little Rock Arkansas Gazette (20 March 1910); 'Woman and the land', Placerville, California, Mountain Democrat (25 June 1910).

77 Thoburn, A standard history of Oklahoma.

78 Hoig, Edmond: the early years; Hoig, The Oklahoma land rush of 1889; Hoig, Edmond: the first century. Interestingly, only Hoig's book on the land rush cites its sources, and he cites only the 1889 Dallas Morning News eyewitness account, which does not mention either the cowcatcher or the petticoat.

79 Crowder, Historic Edmond. Crowder, for his part, held 'grave doubts' about the story's accuracy, but under pressure of publication deadlines simply quoted existing folklore without judgment (James Crowder, personal communication, 16 February 2006).

80 Reese, Women of Oklahoma.

81 Carlile, Buckskin, calico, and lace.

82 A number of articles not only repeat the exaggerated version of the tale, they also quote Hoig as their source for it: 'Was “Classy Lassie" Kentucky Daisey Oklahoma's first liberated woman?', Oklahoma City Daily Oklahoman (1 January 1984); 'Plans for Edmond centennial celebration building up steam', Oklahoma City Daily Oklahoman (30 March 1987); L.J. Jones, 'City lights: Nannette [sic] Daisey colorful character in Edmond history', Edmond Life and Leisure (21 March 2002); 'Edmond statue salutes pioneer spirit', Oklahoma City Daily Oklahoman (30 June 2003). Other recent articles repeat the erroneous version but do not cite Hoig: 'Daisey rode cowcatcher', Oklahoma City Daily Oklahoman (16 April 1989); and 'Edmond pioneer remembered', Oklahoma City Daily Oklahoman (30 April 1993); Shearer, 'Parks group seeks funding'; 'Edmond statue salutes pioneer spirit', Oklahoma City Daily Oklahoman (30 June 2003); and Ray Hibbard, 'Kentucky Daisey stakes claim in Edmond again', Edmond Life and Leisure (25 March 2004), p. 2. In searching Edmond and other regional papers for articles about Daisey I found only two that did not mention the cowcatcher, Kenna Griffin, 'Edmond Parks Foundation to honor female pioneer', Oklahoma City Daily Oklahoman (6 July 2002), p. 9; and Lisa Shearer, 'Finishing touches', Edmond Sun (26 October 2005). Of all articles mentioning Daisey's story, only one (James Coburn, 'Rush for land', Edmond Sun (24 September 2003), p. 1B) mentions the cowcatcher story as 'legend'.

83 J.R. Jeffrey, Frontier women: the trans-Mississippi west, 1840-1880 (New York, Hill and Wang, 1979); Schlissel, Ruiz and Monk, Western women; Jameson, 'The history of women and the West'. In the following paragraphs I focus specifically on the representations of women, though the experiences 
and contributions of Native Americans, African Americans, Asians, Hispanics and others have been similarly under-represented in traditional US Western history.

${ }^{84}$ J.M. Jensen and D.A. Miller, 'The gentle tamers revisited: new approaches to the history of women in the American West', in Irwin and Brooks, eds, Women and gender in the American West, pp. 9-36.

85 D. Brown, The gentle tamers: women of the old wild West was originally published in 1958 and reprinted by University of Nebraska Press in 1981; it is still in print today.

86 Jensen and Miller, 'The gentle tamers revisited'. Women's historian Sandra Myres outlines three very similar stereotypes: the drudge, the brave pioneer mother, and the hell-raising woman-gone-bad (Myres, Westering women). See also K.M. Morin, 'Peak practices', for a rich discussion by a feminist historical geographer of the gendered norms and stereotypes imposed upon and reacted to by Victorian women travelers in the US West.

${ }^{87}$ Myres, I; Jensen and Miller, 'The gentle tamers revisited'; and Reese, Women of Oklahoma.

${ }^{88}$ Jensen and Miller, 'The gentle tamers revisited', pp. 12-14. I have altered the order of the four stereotypes they presented for the purposes of this discussion, but have not altered their descriptions.

${ }^{89}$ Ibid. See also Reese, Women in Oklahoma; and Myres, Westering women.

90 The quote is from R. Slotkin, It's your misfortune and none of my own: a new history of the American West (Norman, University of Oklahoma Press, 1991), p. 613. See also, H.N. Smith, Virgin land: the American West as symbol and myth (Cambridge, MA, Harvard University Press, 1950); R.G. Athearn, The mythic West in twentieth-century America (Lawrence, University of Kansas Press, 1986); G.D. Nash, Creating the West: historical interpretations, 1890-1990 (Albuquerque, University of New Mexico Press, 1991); R. Slotkin, Gunfighter nation: the myth of the frontier in twentieth century America (New York, Athenaeum, 1992); P.N. Limerick, 'The adventures of the frontier in the twentieth century', in J.R. Grossman, ed., The frontier in American culture (Berkeley, University of California Press, 1994), pp. 67-102.

91 White, It's your misfortune; Nash, Creating the West; Limerick, Legacy of conquest, D. DeLyser, 'Authenticity on the ground: engaging the past in a Western ghost town', Annals of the Association of American Geographers 89 (1999), pp. 602-32.

92 M. Lewis, ed., The mining frontier: contemporary accounts from the American West in the nineteenth century (Norman, University of Oklahoma Press, 1967); R.A. Dwyer and R.E. Lingenfelter, Lying on the eastern slope: James Townsend's comic journalism on the mining frontier (Miami, University Press of Florida, 1984); H. Dicken-Garcia, Journalistic standards in nineteenth-century America (Madison, University of Wisconsin Press, 1989); White, It's your misfortune; DeLyser, 'Authenticity on the Ground.'

93 'In the promised land', 26 April 1889.

94 Edmond News (20 November 1891).

95 White, It's your misfortune.

96 Ibid.

97 A. Barra, Inventing Wyatt Earp: his life and many legends (New York, Carroll and Graf Publishers, Inc., 1998).

${ }^{98}$ K. Brownlow, The war, the West and the wilderness (New York, Alfred A. Knopf 1979). See also DeLyser, 'Authenticity on the ground'.

99 J.D. McLaird, Calamity Jane: the woman and the legend (Norman: University of Oklahoma Press, 2005).

100 S.L. Smith, 'Single women homesteaders: the perplexing case of Elinore Pruitt Stewart', Western Historical Quarterly 22 (1991), pp. 163-83; and S.K. George, The adventures of the woman homesteader: the life and letters of Elinore Pruitt Stewart (Lincoln, University of Nebraska Press, 1992); Stewart is quoted on p. 14. Stewart's homestead is today listed on the National Register of Historic Places because of 
her significance as a 'single' woman homesteader. See http://www.cr.nps.gov/nr/ (accessed 17 August 2006). See also E.P. Stewart Letters of a woman homesteader (Boston, Houghton Mifflin, 1914).

101 H.E. Lindgren, Land in her own name: women as homesteaders in North Dakota (Fargo, North Dakota Institute for Regional Studies, 1991); Smith, 'Single women homesteaders', and George, 'The adventures of the woman homesteader'.

102 'Happy in adventure'.

103 Ibid.

104 Myres, Westering women. See Reese, Women of Oklahoma; and Burton, Black, red, and deadly. Burton, for example, notes that 'there were black and Indian gunfighters in prestatehood Oklahoma that deserve a place in our nation's history. These men, both good and bad, were as dangerous as any found in the history of the West', p. ix.

105 E. Jameson, 'The history of women and the West', p. 184

106 'Robbed Miss Daisy', Guthrie Oklaboma Daily Leader (21 December 1893), p. 3. The items Daisey reported missing revealed a less-than austere existence: a 'fine set of silverware, jewelry, rings, etc'.

107 See Irwin and Brooks, Women and gender in the American West.

108 On how Western women adapted their lives to the cult of true womanhood in Victorian times, see Myers, Westering women.

109 'Half has not been told'; accounts describing her as plucky include 'Everything at a premium'; and 'Killed in the Chandler rush'.

110 'Daisy and her gang'.

111 'Their last ghost dance', New York Times 18 April 1892, p. 1.

112 'A fair boomer'.

113 'Annetta Daisy's Amazons'.

114 'Happy in Adventure'.

115 Nanette [sic] Daisy [sic] is dead'.

116 See, for example, M. Domosh, 'With "stout boots and a stout heart"'; and K. Boyer, "Feminist geography in the archive' in the field of geography, and Jameson, 'The history of women and the West', in the field of history.

117 Daisey's statue will be Edmond's largest and most expensive; see http://www.edmondcentennial.com/ projedmondcc.php (accessed on 12 February 2007). Searching both Edmond and Native newspapers and their reports on Edmond City Council meetings yielded only one suggestion of protest: on 24 September 2003, the Edmond Sun noted that Lucile Warrick of the Edmond Historic Trust had suggested that the statue should not focus only on Daisey, but should instead represent a composite of 'all the women who came by train or horse and wagon to the greater Edmond area'. (James Coburn, 'Statue should be more than one woman, official says,' Part B, p. 1.)

118 Jensen and Miller, 'The gentle tamers revisited'.

119 Jameson, 'The history of women and the West', p. 182. Of course, the history of men in the west, while long documented, has also been subject to restrictive stereotyped portrayal and Jameson calls for 'new histories of masculinity [that] have the power to scrutinize the mythic stereotypes of western men that remain powerfully etched in popular culture', p. 193.

120 Savage, Standing soldiers, kneeling slaves, p. 213.6

121 Marita Sturken, Tangled memories: the Vietnam War, the AIDS epidemic, and the politics of remembering (Berkeley, University of California Press, 1997), p. 2.

122 P.N. Limerick, 'The adventures of the frontier in the twentieth century', p. 95. The quote is from the title of her book, The legacy of conquest.

123 Jameson, 'The history of women and the West', p. 194. 
124 Heffernan and Medlicott, 'A feminine Atlas'.

125 Domosh and Morin, 'Travels with feminist historical geography'.

126 Savage, Standing soldiers, p. 7.

127 K.M. Morin and L.D. Berg, 'Emplacing current trends in feminist historical geography', Gender, place and culture 6 (1999), pp. 311-30.

128 See Jensen and Miller, 'The gentle tamers revisited', and Jameson, 'The history of women and the West'.

129 E. Jameson, 'The history of women and the West', p. 184.

130 Flores, Remembering the Alamo, p. x.

131 M.-R. Trouillot, Silencing the past: power and the production of history (Boston, Beacon Press, 1995), p. 26.

132 Edmond Historic Trust member Lucile Warrick argued that the statue's focus on Daisey obscured the influence and leadership of other women settlers (J. Coburn, 'Statue should be more than one woman, official says', Edmond Sun, 24 September 2003, p. 1). I have found no suggestion in local papers that the contributions of non-white settlers or Native Americans be addressed.

133 E.T. Linenthal, Sacred ground: Americans and their battlefields (Urbana, University of Illinios Press, 1991); J. Coburn, 'Historical clock just the start', Edmond Sun (16 May 2006) and http://www.edmondcentennial.com (accessed 17 August 2006). Other projects include the erection of a 'Centennial Clock', two pedestrian bridges, the restoration of Edmond's first schoolhouse, a number of tree-planting efforts, and the publication of James Coburn's Edmonds' Centennial Legacy. Neither is this unusual: as Elizabeth Cook-Lynn points out, nowhere in the United States is there a national monument honoring 'the history of an indigenous nation's defense of itself', (E. Cook-Lynn, 'Introduction', in M. Gonzalez and E. Cook-Lynn, The politics of hallowed ground: Wounded Knee and the struggle for Indian sovereignty [Urbana, University of Chicago Press], pp. 1-12, the quote is from p. 1, italics in original). Still, even statues of Native Americans may contribute to the obscuration of Indian disenfranchisement, as Joanna Brooks has pointed out about statues of Sacagawea, see J. Brooks, 'Sacagawea meet Cogewea: a red pregressive revision of frontier romance', in K. Fresonke and M. Spence, Lewis and Clark: legacies, memories, and new perspectives (Berkeley, University of California Press, 2004) pp. 184-97. See also Walker, 'The difficulty of celebrating an invasion'.

134 Quoted in S. Ruckman, 'Centennial not a time of joy for all', Tulsa World 13 November 2006, p. A1.

135 J. Kent, 'Oklahoma tribes protest Land Run Monument; call for truth in history, Trail of Tears sculpture', News from Indian Country 18 (8 September 2003), p. 2a.

136 J. Morrison, 'Statue raises racism charge', Oneida, NY, Indian Country Today 13 (20 October 1993), p. A1.

137 Heffernan and Medlicott, 'A feminine Atlas', the quote is from p. 125.

138 See Kaufman and Corbett, eds, Her past around us.

139 Hibbard, 'Kentucky Daisey stakes claim in Edmond'.

140 Heffernan and Medlicott, 'A feminine Atlas'.

141 Morin and Berg, 'Trends in feminist historical geography'. 